\title{
CHIŃSKI MODEL ROZWOJU SPOLECZNO-GOSPODARCZEGO I JEGO POTENCJALNA ADAPTACJA W EUROPIE ${ }^{1}$
}

Spójny i prawidłowy rozwój Unii Europejskiej w 2008 r. zahamowany został przez światowy kryzys finansowy i gospodarczy. Jego skutki w Europie, w postaci recesji, naznaczonej rosnącym bezrobociem, niezadowoleniem społecznym i wieloma innymi poważnymi problemami społeczno-ekonomicznymi (szczególnie w tzw. grupie PIIGS: Portugal, Italy, Ireland, Greece, Spain) skłoniły do dyskusji na temat przemodelowania kierunku rozwoju UE i jej państw członkowskich. Unia Europejska w pierwszej dekadzie XXI wieku stanęła bowiem w obliczu podjęcia pilnych działań zwiększających konkurencyjność globalną w sferze produkcji i usług, zatrudnienia, edukacji i nauki, prokreacji oraz w sferze ochrony środowiska naturalnego. Główne wyzwania rozwojowe stojące przed państwami członkowskimi w bieżącej dekadzie zawarte zostały w kompleksowym dokumencie, czyli Strategii „Europa 2020” oraz w postaci działań usprawniających funkcjonowanie strefy euro, z Paktem Fiskalnym i Semestrem Europejskim na czele. W sferze konceptualnej pojawił się ciekawy problem badawczy, dotyczący tego na ile tzw. chiński model rozwoju, który zapewnił ChRL ,milowy skok cywilizacyjny" w ostatnich czterech dekadach i pozycję drugiej, a niedługo pierwszej gospodarki w świecie, jest adaptowalny do uwarunkowań europejskich i ewentualnie - jeśli nie w całości - to jakie jego elementy byłyby możliwe do efektywnego powielenia w Europie. Inny interesujący aspekt dotyczy zagadnienia potencjalnej dominacji chińskiej w świecie, nowego ładu ekonomicznego opartego na chińskich regułach sprawowania władzy oraz handlu i inwestycji, jak i skutków tego procesu dla społeczności międzynarodowej. W poniższym artykule autor stara się udzielić odpowiedzi na te nurtujące pytania badawcze, dotykając nie tylko sfery ekonomicznej i handlowej, ale też społecznej, kulturowej, filozoficznej, a nawet religijnej.

\section{PROCES TRANSFORMACJI GOSPODARKI CHIŃSKIEJ. REFORMY DENG XIAOPINGA}

Chiny uznawane są za jedną z kolebek cywilizacji ludzkiej. W przeszłości określane też jako Serica, Kataj (Kitaj) czy Sina są państwem i cywilizacją o niezwykle długiej i bogatej historii, kulturze i tradycji, liczącej niemal cztery tysiące lat. Wno-

${ }^{1}$ Prezentowany artykuł realizowany jest w ramach grantu badawczego: Unia Europejska wobec przyspieszonego rozwoju Chińskiej Republiki Ludowej [The European Union and the accelerated development of the People's Republic of China]. Konkurs NCN OPUS 11 (16.12.2013). 
siły one w przeszłości i nadal wnoszą wielki wkład w rozwój świata i to nie tylko za sprawą słynnych wynalazków sprzed stuleci (szczególnie tzw. „Czterech Wielkich Chińskich Wynalazków”, czyli kompasu, prochu strzelniczego, papieru i druku), znakomitej i urozmaiconej smakowo kuchni czy osiągnięć medycyny naturalnej, ale także za sprawą znaczenia i roli politycznej i gospodarczej jakie państwo to współcześnie posiada $\mathrm{w}$ ramach światowego porządku ekonomicznego. Po latach upokorzeń, stagnacji rozwojowej i odcięcia od świata, od końca lat 70. minionego stulecia władze Chińskiej Republiki Ludowej podejmują liczne starania, aby państwu i społeczeństwu przywrócić należne mu miejsce, prestiż i znaczenie. Odnosząc się do owych starań R. Gifford w swej wciągającej czytelnika książce Chińska droga odnotował: „W Chinach da się dostrzec wielkie napięcie w myśleniu o własnej historii. Wszyscy Chińczycy znają wspaniałą przeszłość swojego kraju. Chińska cywilizacja zaczęła zmierzać ku dominującej pozycji w świecie w VII i VIII stuleciu i sięgnęła zenitu w XII wieku, kiedy Europa tkwiła nadal w mrokach średniowiecza. Wielu ludzi na Zachodzie słyszało o czterech wielkich wynalazkach, jakimi były papier, druk, proch strzelniczy i kompas, które w Chinach pojawiły się znacznie wcześniej niż w krajach zachodnich. Ponadto można przypisać Chińczykom cały skarbiec innych wynalazków, które utorowały sobie drogę na Zachód. Należą do nich ster zawiasowy, most wiszący na łańcuchach żelaznych, techniki głębokich wierceń, śluzy, latawce, kusze, by wymienić tylko kilka przykładów. W tym czasie Chiny były o wiele silniejsze, bogatsze i bardziej zaawansowane technologicznie niż Europa i w ogóle cały świat" (Giford, 2013: 68).

W kilkudziesięcioletniej, powojennej historii Chińskiej Republiki Ludowej (ChRL) wyróżnić można dwa główne okresy rozwojowe. Pierwszy, ,rewolucyjny”, inspirowany koncepcjami Mao Zedonga, obejmował lata 1949-1977. Drugi, trwający de facto do dziś, znany jest jako kurs ,reform i otwarcia na świat”. Zapoczątkowany został on pod koniec 1978 r. przez chińskiego wizjonera reform ekonomiczno-społecznych i politycznych Deng Xiaopinga. Przyniósł on zasadnicze przewartościowanie koncepcji i założeń z czasów rządów Mao. O ile w pierwszym okresie odrodzenie potęgi miało nastapić poprzez rewolucję i budowę autarkicznego systemu gospodarczego, o tyle w drugim - rozwój następować miał poprzez modernizację i tworzenie kompleksowej siły państwa. Jak pisze J. Rowiński, charakterystyczną cechą etapu maoistowskiego było powielanie radzieckiego modelu rozwoju w sferze ideologicznej, politycznej, gospodarczej, społecznej i militarnej. Znalazło to swój wyraz w katastrofalnej w skutkach koncepcji „,wielkiego skoku” i komunizacji wsi z lat 1958-1960, a później w niemniej tragicznej w wyrazie idei „,wielkiej proletariackiej rewolucji kulturalnej” z lat 1966-1976. Siłą napędową ,pościgu za światem” miała być „permanentna rewolucja” ze „stale zaostrzającą się walką klasową”, a jego instrumentami - niekończące się ogólnokrajowe kampanie polityczne wychowania ideologicznego i stosowane na wielką skalę represje wobec tzw. wrogów klasowych. W dziedzinie gospodarczej celem pozostawało przezwyciężenie zacofania i prześcignięcie innych mocarstw. Jednak po krótkim okresie szybkiego, ekstensywnego wzrostu, w wyniku nieudolnych prób jego sztucznego przyspieszenia doszło do totalnego załamania gospodarczego i zastoju państwa w wielu wymiarach. W polityce zagranicznej - jak dowodzi ten ceniony polski specjalista - było podobnie. Po kilkunastu latach konstruktywnych działań zyskujących międzynarodową aprobatę, również nastąpił niekorzystny zwrot. W latach 
60. XX w. obawy adresowane były wobec „,agresywnych intencji czerwonych Chin”, pogłębiając ich światową izolację (Rowiński, 2008: 44).

„Wielki skok” jak pisze J. Sachs był wymyślonym przez Mao Zedonga i kompletnie bezsensownym programem przyspieszenia uprzemysłowienia przez wprowadzenie „przydomowego” wytapiania stali. Milionom chłopów w całym kraju kazano zaprzestać pracy na roli i przystapić do wytwarzania stali w małych, niewydajnych i absolutnie nielogicznie pomyślanych przydomowych piecach hutniczych. Polityka ta w rezultacie doprowadziła do gigantycznej klęski głodu. „Rewolucja kulturalna”, która zaczęła się w 1966 r., była wymyśloną przez Mao i trwającą dziesięć lat, próbą doprowadzenia do permanentnej rewolucji przez radykalne zmiany w planowaniu i procesach zarządzania krajem. Zmieniła stratyfikację społeczną całego chińskiego społeczeństwa, pozbawiła ludzi środków do życia, prowadziła do samobójstw i wysiedleń oraz na dekady przerwała edukację całego pokolenia chińskiej młodzieży. Odnotować wypada, że wielu dzisiejszych chińskich uczonych i przywódców politycznych przeżyło to dziesięciolecie $\mathrm{w}$ bardzo trudnych warunkach egzystencji i niemal niewolniczej pracy na roli. Bowiem to właśnie „wsie miały otoczyć miasta” i dominować w maoistycznej strategii rozwoju państwa. Dopiero po śmierci Mao w 1976 r., aresztowaniu „,bandy czworga” oraz dojściu do władzy Deng Xiaopinga w 1978 r. nastapił etap ,wielkiego otwarcia Chin na świat” (Kłosiński, 2008: 514; Sachs, 2005).

„Odrodzenie wielkości chińskiej nacji” i przywrócenie Chinom należnego miejsca światowego mocarstwa w społeczności międzynarodowej od wielu lat pozostawało i nadal pozostaje podstawowym dążeniem przywódców, elit rządzących i społeczeństwa chińskiego. Działo się tak niezależnie od tego, czy Chiny były cesarstwem, republiką czy demokracją ludową. Dążenie to wynika z historycznej pamięci o wielkości i potędze państwa. Było i jest inspirowane także przez idee, wzorce i zasady. Było też reakcją na „wiek hańby i poniżenia” zapoczątkowany klęską w pierwszej wojnie opiumowej (1839-1842)2.

Odejście od „modelu rewolucyjnego" nastąpiło dopiero w okresie rządów Denga, który uznał, że decydującymi warunkami budowy potęgi Chin i odrodzenia narodowego będą rozwój gospodarczy i gruntowna modernizacja kraju. Deng przed chińską polityką postawił do realizacji trzy najważniejsze zadania: „sprzeciw wobec hegemonizmu i utrzymanie pokoju”, ,reunifikacja kraju” i program „,czterech modernizacji”. Program „czterech modernizacji” dosyć szybko zarzucono, zastępując go dwoma nowymi terminami, obowiązującymi do dziś, czyli gaige - „reforma” oraz kaifang - „otwarcie na świat”. W ramach paradygmatu rozwojowego, zwanego popularnie gaige-kaifang, Deng Xiaoping w połowie lat 80. minionego wieku dodatkowo zaproponował i wdrożył, nawiązujący do starej chińskiej tradycji budowy merytokracji (rządów oświeconych elit), program stałej wymiany „pokoleń” rządzących elit. Z założenia - za każdym razem - miały być one coraz młodsze i coraz lepiej wykształcone.

${ }^{2}$ Pierwsza wojna opiumowa, znana także jako I wojna chińsko-brytyjska (1839-1842) miała miejsce między Wielką Brytanią a chińską dynastią Qing. Miała ona na celu wymuszenie na cesarskich Chinach ustępstw handlowych, m.in. w handlu opium. Jej finałem było podpisanie traktatu nankińskiego, który był pierwszym z nierównoprawnych traktatów wymuszonych na Chinach w XIX i XX w. przez mocarstwa światowe i który na długie dekady zdecydował o losach Hongkongu, który przeszedł pod jurysdykcję brytyjską. 
Rozwinięcie tych założeń legło u podstaw formułowanej później „,wielkiej strategii” stopniowego otwarcia się na świat i rosnącej globalnej roli Chin (strategia Go Global) oraz realizacji „,chińskiego snu” związanego z hasłem „wielkiego odrodzenia/renesansu narodu chińskiego". W „wielkiej strategii Chin” okres do roku 2020 i dalej do połowy XXI w. określany jest mianem „,czasu strategicznej szansy”. Założenia przyjęte do 2020 r. przewidują osiagnięcie czterech głównych celów rozwojowych: długookresowego, stałego i zrównoważonego wzrostu gospodarczego, statusu mocarstwa, poziomu średniego dobrobytu i podniesienia międzynarodowej zdolności konkurencyjnej kraju (Rowiński, 2008: 47).

Od drugiej połowy lat 70. XX wieku ChRL pod przywództwem Deng Xiaopinga wznowiła stosunki dyplomatyczne oraz współpracę handlową ze światem. Gospodar$\mathrm{ka}$, po traumatycznych doświadczeniach związanych z autarkicznym modelem nakazowo-rozdzielczym obrała zdecydowany kurs w kierunku systemu rynkowego, choć z uwzględnieniem tzw. chińskiej specyfiki, czyli znaczącej, nadzorczo-kontrolnej, regulacyjnej i stymulującej roli państwa w kreowaniu przemian rynkowych. Stabilny i wysoki (przynajmniej do czasów globalnego kryzysu 2008+) wzrost PKB w ChRL jest przykładem unikatowego sukcesu, jaki tak duża gospodarka odniosła w tak krótkim czasie. Począwszy od 1978 r., gospodarka chińska stopniowo przeobrażała się z modelu gospodarki centralnie planowanej i w znacznej mierze zamkniętej na handel międzynarodowy, w gospodarką zbliżoną do modeli wolnorynkowych, z intensywnie rozwijającym się sektorem prywatnym. Pamiętać bowiem należy, że jeszcze na początku XIX wieku Chiny były największą gospodarką w świecie, a chińskie PKB stanowiło niemal $30 \%$ światowego PKB. Dla porównania, w owym okresie łączne PKB krajów Europy Zachodniej oraz Stanów Zjednoczonych stanowiło zaledwie 20\% światowego PKB. W początkach XX wieku udział chińskiego PKB w światowej gospodarce spadł do $11 \%$ i zmniejszał się w kolejnych latach, co było jednym ze skutków licznych konfliktów zewnętrznych i wewnętrznych mających miejsce w Państwie Środka. Z perspektywy historycznej widać więc, że trwający do 2008 r. gwałtowny wzrost gospodarczy Chin nie był więc zjawiskiem nowym, a raczej powrotem do normalności, czyi statusu wiodącej gospodarki w świecie (Inwestowanie w Chinach, 2012).

Obecni przywódcy chińscy tzw. piątej generacji, kontynuatorzy reform z końca lat 70. XX wieku - prezydent Xi Jinping, premier Li Keqiang i pozostali członkowie Biura Politycznego KPCh - do dziś doskonale pamiętaja, twórczo interpretują i efektywnie wdrażają dyrektywę Denga, wizjonera i protoplasty reform, który w czerwcu 1984 r. stwierdził: „Nasza linia polityczna sprowadza się do tego, by kładąc nacisk na cztery modernizacje (rolnictwa, przemysłu, obrony narodowej oraz nauki, techniki i oświaty) wytrwale rozwijać siły wytwórcze i w żadnym wypadku nie osłabiać tego podstawowego ogniwa w naszej pracy"3.

Przywódcy chińscy - Xi i Li - nie tylko poważają, ale jak wspomniano, w duchu przemyśleń Denga ewolucyjnie rozwijają i udoskonalają jego strategię rozwoju, pragmatycznie dostosowując kolejne elementy reform do nowych wyzwań rozwojowych kraju. Deng Xiaoping, przeszedł do historii jako światły mąż stanu i skuteczny polityk, ale też pod kątem licznych haseł, których był twórcą, które są znane i bardzo popular-

${ }^{3}$ Pozostali członkowie BP KPCh to: Zhang Dejiang (nr 3), Yu Zhengsheng (nr 4), Wang Qishan (nr 5), Liu Yunshan (nr 6) oraz Zhang Gaoli (nr 7). 
ne w Chinach do dziś, zarówno wśród elit, jak i szerokich mas społecznych. U progu prorynkowych reform wystosował on do nich istotne wezwanie, brzmiące: „Bogaćcie się”. Jak pisze J. Gittings „Za przyzwoleniem Denga miliony Chińczyków «zanurzyły się w morzu biznesu». Od tej pory każdy «mógł zostać biznesmenem (albo bizneswoman)», co było uaktualnioną wersją hasła z końca lat 50. głoszącego, że «każdy powinien zostać żołnierzem». Przez całą połowę lat 90. panowała gorączka przedsiębiorczości, jako że «każdy», jak się wydawało, odpowiedział na ponowione przez Denga zaproszenie, aby «wzbogacić się najpierw». Pociągi, i w coraz większym stopniu samoloty pasażerskie, były zatłoczone niedoszłymi przedsiębiorcami ryzykującymi podróże we wszelkich kierunkach, z północnego wschodu po Tybet, ale szczególnie na południowe wybrzeże, aby zbić fortunę. Gorączka gospodarcza stała się częścią nowej popularnej kultury, w której miliony członków kadry wraz z rodzinami uczestniczyły równie entuzjastycznie jak wszyscy inni” (Gittings, 2010: 125).

Według A. Bruneta i J-P. Guicharda, Deng mimo iż nigdy nie przyznał tego publicznie, świadomie i definitywnie postawił na powrót do kapitalizmu, choć w specyficznym chińskim wydaniu. Zrywając z komunistycznym dogmatem o kolektywnej własności środków produkcji, sprywatyzował wiele przedsiębiorstw państwowych, wprowadził decentralizację zarządzania w tych z nich, które pozostały publiczne, zezwolił i wręcz zachęcał do tworzenia firm prywatnych w wielu sektorach działalności. Restauracja „kapitalizmu po chińsku” w czasach jego rządów zaczęła się na wsi: komuny ludowe stopniowo zastępowano tam gospodarstwami rodzinnymi, dzięki czemu wolny rynek powoli, ale skutecznie zaczął się rozwijać. Następnie, w związku z targami kantońskimi, istotnymi dla rozwoju działalności podwykonawczej małych i średnich przedsiębiorstw, powstały bardzo ważne dla przyjętej strategii rozwoju specjalne strefy ekonomiczne na południu i wschodzie kraju, z SSE Shenzhen na czele. ChRL przejęła tym samym rolę ,warsztatu świata” (Brunet, Guichart, 2011: 72).

Autorzy ci chiński model rozwoju ChRL nazywają ,kapitalizmem totalitarnym”, będącym też „kapitalizmem patriotycznym”, w którym przedsiębiorstwa chińskie, szczególnie duże firmy państwowe, uzyskują liczne wsparcie i priorytet kosztem eksporterów zagranicznych. W ich opinii Chiny są jednocześnie krajem kapitalistycznym i totalitarnym, co daje im kilka niewątpliwych atutów ekonomicznych. Są to na przykład bardzo niskie koszty pracy (w dużym stopniu dzięki zasadom unikatowego systemu meldunkowego zwanego hukou), które połączone ze znaczącym niedoszacowaniem waluty renminbi - RNB, sztucznie poprawiają konkurencyjność eksportu i przynoszą duże nadwyżki handlowe. Problem ten zresztą stanowi przedmiot zainteresowania wielu innych autorów, w tym D. Cohena (2011) w pracy pt. Prosperity słabościt.

Związani z Dengiem pragmatyczni przywódcy chińscy zaczęli posługiwać się dwo-

${ }^{4}$ D. Cohen w najnowszej historii gospodarczej ChRL widzi pewne podobieństwo do strategii japońskiej, dotyczące trzech głównych elementów. Pierwszy z nich polega na systematycznym utrzymywaniu niskiego kursu waluty w celu pobudzania eksportu, co było i jest typowe dla większości państw azjatyckich. Skuteczność tej polityki najpierw udowodniła Japonia, a następnie cztery „tygrysy azjatyckie", które poszły jej śladem, tj. Tajwan, Korea Południowa, Hongkong oraz Singapur. Drugą zasadą chińskiej polityki, wzorowaną na japońskiej, jest intensywny rozwój edukacji, a trzeci element to wysoka stopa oszczędności społeczeństwa chińskiego, pozwalająca gromadzić znaczne rezerwy dewizowe (ale też ograniczająca popyt wewnętrzny), co stanowi obecnie w Chinach spory problem rozwojowy. Szerzej: D. Cohen (2011), Prosperity słabości, Warszawa. 
ma innymi, stosowanymi do dziś, hasłami programowymi. Pierwsze mówiło o tym, że ,praktyka jest jedynym kryterium prawdy”, drugie natomiast - akurat wyjątkowo popularne w Chinach - powiada, że „należy iść przez rzekę, czując kamienie pod stopami”. Innymi słowy, od początku reform opowiedziano się za praktyką i pragmatyzmem i odejściem od ideologii, a równocześnie za stopniowym, etapowym i ostrożnym wprowadzaniem zmian, czyli gradualizmem. Inne elementy „chińskiego modelu rozwojowego" (chiń. Zhongguo Moshi) to autorytaryzm i kontrola funkcjonowania rynku dominującego nad demokracją, kolektywne podejmowanie decyzji, powrót do chińskich korzeni, w tym przede wszystkim do patriarchalnego i hierarchicznego ducha konfucjanizmu, odrzucenie wzorców zachodnich przy równoczesnym obserwowaniu zachodzących w świecie zmian i twórczym ich naśladowaniu w wybranych aspektach. Kolejne cechy chińskiego modelu to umiejętne korzystanie z tej części dorobku światowego, który mógłby być dla Chin przydatny, wykalkulowane i pragmatyczne podejście do procesu globalizacji z próbą wpływu na kształt tego procesu, prowadzenie procesu rozwojowego przez państwo oraz zachowanie w wybranych, strategicznych dziedzinach interwencjonizmu państwowego, szerokie otwarcie własnego rynku na kapitał obcy, ale na określonych zasadach i jedynie selektywnie, przy stałym preferowaniu kapitału rodzimego 5 (Gittings, 2010: 127).

Lee Kuan Yew, twórca potęgi gospodarczej Singapuru i niedawno zmarły wielki międzynarodowy autorytet pisał, że każdy Chińczyk chce silnych i bogatych Chin, państwa tak dostatniego, rozwiniętego i kompetentnego pod względem technicznym jak Ameryka, Europa i Japonia. Wszechmocną siłę na nowo stanowi tam rozbudzone poczucie własnego przeznaczenia. Chiny chcą być największym mocarstwem świata, a ich sposób rozumowania wywodzi się ze świata sprzed ery kolonialnej oraz wieku wyzysku i poniżenia, jakie ta przyniosła ze sobą. Zgadza się on z Henry Kissingerem, który dowodził, że: „W szczytowym punkcie strefa chińskiej kultury obejmowała obszar przekraczający rozmiarami jakiekolwiek państwo europejskie, więcej nawet - porównywalny z powierzchnią całej kontynentalnej Europy. Chiński język i chińska kultura, a także polityczne rozporządzenia cesarza docierały na wszystkie znane tereny: od stepów i sosnowych lasów na graniczącej z Syberią północy po tropikalne dżungle i tarasowe pola ryżowe na południu; od portów, kanałów i rybackich wiosek na wschodnim wybrzeżu po surowe pustkowia Azji Środkowej i pokryte lodem szczyty himalajskiej granicy"6 (Kissinger, 2014: 28).

${ }^{5}$ Znanych i popularnych jest znacznie więcej przysłów i maksym Denga, które na pamięć zna niemal każdy Chińczyk. Przykładem jest choćby ta, która w kontekście podkreślenia wagi rachunku ekonomicznego i pragmatyzmu w dążeniu do pomnażania zysków, mówi o tym że ,...nieważne czy kot jest biały czy czarny, ważne aby myszy łapał" lub ta, w której nawoływał on by w pierwszej kolejności zając się budową potęgi państwa, a w stosunkach z wielkimi mocarstwami, począwszy od USA, „unikać konfrontacji i szukać możliwości współpracy”. Zgodnie z nią - Chiny, owszem, mają być potęgą, ale najpierw muszą zbudować jej ekonomiczne i materialne podstawy. Następnie wskazane jest ,,pokojowe zjednoczenie” z Tajwanem, przy równoczesnym dbaniu o cele nadrzędne, o jakich też już otwarcie się mówi, czyli o zapewnieniu całemu narodowi „umiarkowanego dobrobytu” i doprowadzeniu do „,wielkiego renesansu chińskiego narodu”.

${ }^{6} \mathrm{~W}$ tych warunkach zrodziło się pojęcie sinocentryzmu. Jego istotą jest określenie Chin jako Państwa Srodka (Zhongguo). To poczucie własnej wyjątkowości było logiczną konsekwencją określonej wizji swego położenia i otoczenia. Jest ono nadal mocno obecne w chińskiej świadomości i pozostaje charakterystyczną cechą postrzegania własnego miejsca w świecie oraz podejścia do 
Strategia Chin wobec Azji Południowo-Wschodniej jest więc w opinii L. K. Yewa dość prosta: Chiny mówią regionowi: ,rośnij wraz ze mną”. Ogromny rynek i rosnąca siła nabywcza sprawiają, że Chiny wchłoną w końcu kraje Azji Południowo-Wschodniej (Japonię i Koreę Południową także) w obręb swojego systemu gospodarczego. Dalej wchłaniać będą inne kraje i to bez konieczności stosowania siły. Zasadnicze tendencje ustalać będzie gospodarka, a rosnące wpływy ekonomiczne Chin zwalczyć będzie bardzo trudno. ChRL kładzie więc nacisk na rozszerzanie swych wpływów przez gospodarkę i liczne elementy soft power. W sensie geopolitycznym interesuje je obecnie posługiwanie się $\mathrm{w}$ polityce zagranicznej dyplomacją, a nie siła. Nie zamierzają przy tym stać się liberalną demokracją, bojąc się chaosu i upadku - konkluduje Yew ${ }^{7}$ (Allison, Blackwill, Wyne, 2013: 53).

Obrazowo do tej kwestii odniósł się też inny ceniony znawca problemu R. Kagan, według którego:

„Sześćdziesiąt lat temu Chiny leżały na łopatkach, rozdarte konfliktami wewnętrznymi, przygniecione obcą okupacją, bezradne, biedne i pogrążone w izolacji. Dziś wynurzają się jako geopolityczny i gospodarczy gigant, będący w stanie zapewnić bezpieczeństwo swoich rozległych granic. Ich gospodarka ściga się o palmę pierwszeństwa z największymi gospodarkami na świecie. Ich siła militarna stale rośnie, a polityczne wpływy rozszerzają się w tym samym tempie, co gospodarka i armia. Być może żaden kraj na świecie nie przebył nigdy tak długiej drogi w tak krótkim czasie. [...] Przez ponad tysiąc lat były dominującą siłą w Azji, jedyną rozwiniętą cywilizacją na oceanie barbarzyństwa, rozwijającą się we własnym, niezależnym od innych kulturowo i politycznie uniwersum - w Państwie Środka. Na początku XIX wieku Chiny znalazły się w stanie krytycznym i odkryły nagle, że zostały ,wyrzucone na obrzeża” świata, który stał się eurocentryczny. «Wiek upokorzenia», który nastąpił, był szczególnie bolesny, bo towarzyszył mu spadek z wyżyn dawnej świetności. [...] Rozwijająca się w błyskawicznym tempie gospodarka Chin nie tylko uwikłała je w sieć nowych powiązań ze światem. Dała ona Chińczykom i ich przywódcom nowe poczucie pewności siebie, rozwój dumy narodowej i niepozbawione podstaw przekonanie, że do nich należy przyszłość. Odkrycie własnej ekonomicznej przebojowości ożywiło stare uczucie tego, co Amerykanie nazywają «potwierdzającym się przeznaczeniem», głęboko zakorzenione przekonanie, że Chiny były kiedyś i znów staną się wiodącą siłą na świecie. [...] Rośnie poczucie narodowej dumy. Rząd chiński nie wstydzi się już mówić o przywróceniu narodowi honoru. Duma ze wzrostu statusu międzynarodowego stała się jednym z najważniejszych źródeł legitymizacji rządzącej Komunistycznej Partii Chin. Towarzyszy temu populistyczny nacjonalizm,

świata. Rodząca się nowa ideologia narodowa wynika z uzasadnionego poczucia dumy z dokonanego w ostatnim okresie skoku rozwojowego i rosnącej roli Chin na arenie międzynarodowej. Jednym z filarów tej ideologii pozostaje ,powrót do korzeni kulturowo-cywilizacyjnych” i świetności Niebiańskiego Cesarstwa, z czym wiąże się niezachwiane przekonanie, iż odzyska ono swoje centralne miejsce „pod kopułą Niebios” (tian xia). Wiek „hańby i poniżenia”, czyli wiek XIX i jego trzy wojny opiumowe i ich następstwa, pozostawił głęboki ślad w mentalności chińskiej i nadal znacząco wpływa na postrzeganie świata i zachowanie Chińczyków. Z tych bolesnych doświadczeń wynika ich dzisiejsze szczególne wyczulenie na bezwzględne respektowanie ich suwerenności, duma narodowa oraz to, co uważane jest za nierównoprawne traktowanie, a także na poszanowanie integralności terytorialnej Chin. Utrwalało to świadomie wzmacnianą przez wiele lat przez system edukacji i propagandy w ChRL „mentalność ofiary”, skrzywdzonej przez obcych, która ma słuszne prawo domagać się rekompensaty i specjalnego traktowania, podobnie jak podejmować wszelkie działania, jakie uzna za stosowne, aby zmienić ten niesprawiedliwy stan rzeczy.

7 Ibid. 
czasami wymierzony w Japonię, a czasami w Stany Zjednoczone. Chińskie ambicje i pragnienie prowadzenia niezależnej polityki strategicznej, poczucie rosnącej rangi chińskiego państwa, wrażliwość na punkcie statusu i dumy narodowej, wreszcie rozwój armii, realizowany w celu utwierdzenia i obrony nowo nabytej pozycji w świecie, nie są działaniami ponowoczesnego mocarstwa ani mocarstwa dążącego do utrzymania status quo, lecz typowymi działaniami wzrastających mocarstw obserwowanymi w przeszłości. [...] W projekcji KPCh «Zachód traci monopol na realizację procesu globalizacji», a przykład sukcesu modelu autorytarnego, pokazuje chińską strategię budowania dobrobytu i stabilności bez konieczności liberalizacji politycznej" (Kagan, 2009: 42).

W podobnym duchu do ewolucji tej odnosi się M. Dillon, w opinii którego wysoko postawione postacie chińskiego życia politycznego we wczesnym okresie programu reform twierdziły, że tworzą specyficzną chińską odmianę socjalizmu, w oficjalnym żargonie „socjalizmu o cechach chińskich”. Jednak koncepcja ta - w jego opinii - okazała się niczym więcej niż retoryką etnocentryczną. Marksistowska czy komunistyczna ideologia polityczna nie jest już w XXI w. istotnym czynnikiem rozwoju w Chinach i nawet - bez przekonania - podejmowane próby przywołania elementów epoki Mao, czyli „ducha Yan’anu, poświęceń żołnierza Lei Fenga czy wzorowego urzędnika Jiao Yulu", ponawiane w latach 90 . XX w., znikły i przestały mieć większe znaczenie. Liczyć zaczęła się wyłącznie gospodarka. Według M. Dillona, tym czego obawiają się najbardziej ostrożni i konserwatywni przywódcy ChRL, zgodnie z tradycją konfucjańskich władców z przeszłości, jest dziś „,chaos i nieporządek”8.

Zainicjowane przez Denga w drugiej połowie lat 70. XX w. reformy gospodarcze, polityka otwarcia kraju na świat i tworzenie socjalizmu o chińskiej specyfice, przyniosły w efekcie dynamiczny wzrost gospodarczy. Przedstawiony na III Plenum KC KPCh w grudniu 1978 r. nowy kurs w społeczno-politycznym rozwoju kraju stworzył podstawę do zainicjowania kompleksowego programu reform. Jak dowodzi D. Guthrie ,w ciagu dwudziestu pięciu lat Chiny osiagnęły postęp, na jaki wiele krajów pracowało pół wieku" (Pieczonka, 2012: 2). Ponadto stały się one członkiem Rady Bezpieczeństwa ONZ oraz wielu organizacji regionalnych i międzynarodowych, w których wciąż odgrywają ważną i aktywną rolę. Przystąpienie ChRL do Światowej Organizacji Handlu (WTO) w 2001 r. było kolejnym ważnym etapem rozwoju, dzięki któremu państwo pełniej włączyło się do systemu globalnego handlu. Jak wynika z wielu analiz, w tym autorstwa B. Liberskiej, dzięki reformom przeprowadzonym po 1978 r. i polity-

${ }^{8}$ Yan'an - miasto o statusie prefektury miejskiej w środkowych Chinach, w prowincji Shaanxi. W latach 1935-1948 było siedzibą Komunistycznej Partii Chin, której bojownicy przedostali się do Yan'anu w czasie Długiego Marszu. Chińscy komuniści uważają miasto za kolebkę rewolucji, która doprowadziła w 1949 r. do powstania Chińskiej Republiki Ludowej.

Lei Feng - żołnierz Chińskiej Armii Ludowo-Wyzwoleńczej. Wkrótce po śmierci przedstawiany był przez propagandę jako uosobienie bezinteresowności i skromności, jawił się także jako człowiek zupełnie oddany Mao Zedongowi. W pośmiertnej kampanii zatytułowanej „Ucz się od towarzysza Lei Fenga” rozpoczętej przez Mao w 1963 r. młodzież Państwa Środka była masowo indoktrynowana, aby iść za jego przykładem.

Jiao Yulu - chiński urzędnik i polityk, będący symbolem uczciwości w partii i człowieka niestrudzenie poświęcającego się dla innych i kraju. Postać za życia i po śmierci uważana za wspaniały przykład do naśladownictwa, zwiększającego morale i stanowiącego zachętę do ciężkiej pracy. Szerzej: M. Dillon (2012), Chiny. Historia współczesna, Warszawa; B. Góralczyk (2010), „Chiński feniks", Paradoksy wschodzqcego mocarstwa, Warszawa. 
ce otwarcia gospodarka chińska w ostatnich dekadach stała się najszybciej rozwijającą się gospodarką świata. Model, który przyjęto nazywa ona globalizacja kontrolowana (zarządzaną). Oznacza on, że dane państwo otwiera się na globalizację, ale na swoich własnych warunkach, nie rezygnując z możliwości kontroli nad przepływami kapitału i nad działaniami inwestorów zagranicznych, przyjmując selektywnie reguły wolnorynkowej gry i otwierając się na konkurencję tylko w wybranych sektorach. Chiński model rozwojowy, w opinii B. Liberskiej, jest atrakcyjny dla wielu państw rozwijających się, które przeżywały w przeszłości rozmaite kryzysy gospodarcze lub finansowe w efekcie stosowania neoliberalnych zaleceń MFW i pełnego otwarcia swych rynków na konkurencję. Część z nich, np. w Afryce, Ameryce Łacińskiej czy Azji Centralnej uznaje, że chiński wzorzec ekonomiczny, powiązany z zamierzonym deficytem demokracji i autorytarnym stylem sprawowania władzy jest rozwiązaniem pozwalającym ustrzec się kryzysowych sytuacji w przyszłości, zapewniając szybszy i bardziej stabilny rozwój społeczno-ekonomiczny (Liberska, 2010: 331-358) ${ }^{9}$.

W opinii M. Leonarda, który zdobył uznanie wydaną w 2005 r. książką pt. Why Europe Will Run the 21th Century, najbardziej bezpośrednią konsekwencją gwałtownego rozwoju ChRL było to, że nie nastapiło oczekiwane ,upowszechnienie zachodniej demokracji liberalnej”. W pierwszych trzydziestu latach realizacji chińskiego programu reform koncentrowano się przede wszystkim na przyłączeniu Chin do świata, przyjęciu od Zachodu i przyswojeniu sobie know-how dotyczącego gospodarki i polityki zagranicznej. Kolejne trzydzieści lat reform w jego opinii będzie czasem bardziej pewnych siebie Chin, rozszerzających swoją władzę i formujących nowy kształt świata. Dla rządów w Afryce, Azji Środkowej, Ameryce Łacińskiej, a nawet na Bliskim Wschodzie rozwój potęgi ChRL oznacza przy tym, że wybór nie ogranicza się już do dwóch możliwości: asymilacji z Zachodem bądź izolacji. ChRL nie narzuci nowego porządku globalnego, ale stworzy alternatywny biegun i filozofię, która będzie

${ }^{9}$ Por. B. Liberska (2010), Czy Beijing consensus zastapi waszyngtoński?, http://www.obserwatorfinansowy.p1/2010/03/11/. Sukcesy gospodarcze Chin stanowią unikatowe doświadczenie we współczesnej gospodarce światowej. Przyjęty przez Chiny model rozwoju pozwolił na transformację gospodarki izolowanego, zacofanego i biednego kraju rolniczego w drugą potęgę gospodarczą świata. Dzięki stopniowym reformom społeczno-gospodarczym ponad $400 \mathrm{mln}$ obywateli z $1350 \mathrm{mln}$ ogółem wydobyło się ze skrajnej nędzy, a warunki życia większości społeczeństwa odczuwalnie poprawiły się. Inwestycje zagraniczne, szczególnie w formie BIZ, napływ technologii z tym związany oraz strategia maksymalizacji eksportu stworzyły w ostatnich dekadach podstawy dynamicznego wzrostu gospodarczego. Reformy i otwarcie gospodarki wpłynęły nie tylko na wielkość i strukturę gospodarki, ale przyczyniły się do znacznego wzrostu pozycji Chin w gospodarce światowej. Chiny nie tylko już uczestniczą w procesach globalizacji, ale w dużym stopniu je kształtują w ramach specyficznego modelu rozwojowego, unikatowej odmiany „kapitalizmu państwowego” (socjalizmu rynkowego), realizowanego pod kierunkiem KPCh. Przyjęta koncepcja modernizacji zakładała reformy gospodarcze bez reform demokratycznych oraz decydującą rolę państwa w wytyczaniu kierunków rozwoju w kolejnych pięciololetnich planach rozwoju, które wprowadza się konsekwentnie i stopniowo. Państwo decydowało i nadal decyduje o zakresie, szybkości, narzędziach oraz kierunkach uczestniczenia społeczeństwa w procesie globalizacji. W związku z tym chińskie podejście do globalizacji, wielu autorów za amerykańskim noblistą J. Stiglitzem określa jako „kontrolowaną lub zarządzaną globalizację" (ang. managed globalization). Polityka państwa stale dostosowuje się do zmieniających się globalnych warunków ekonomicznych i finansowych, pod kątem ograniczenia zagrożeń dla stabilizacji i utrzymania wysokiego wzrostu PKB. Szerzej K. Kłosiński (2008), Chiny polityka otwartych drzwi ,, China OpenDoor Policy”, op. cit. 
równoprawna z amerykańskimi próbami zbudowania układu sił sprzyjających demokracji, europejską skłonnością do multilateralizmu bądź islamską nadzieją na rządy teokratyczne. Trudno nie zgodzić się z opinią M. Leonarda, że ChRL dążąc do kontroli nad procesami globalizacji, chce stworzyć świat, w którym to rządy decydowałyby o losie swych państw, a nie stawały się (jak to często dzieje się obecnie) obiektami zależnymi od globalnego kapitału korporacji i amerykańskiej polityki zagranicznej. Chiny od reszty świata oczekują inwestycji, technologii i dostępu do rynków, ale bez konieczności przyjmowania zachodniego systemu wartości. Pragną polityki zaangażowania się w sprawy świata, ale na własnych warunkach. „Kapitalizm Żółtej Rzeki”, dyktatura deliberatywna i zagregowana potęga państwa to podstawowe elementy nowej chińskiej filozofii kształtowania procesu globalizacji. Państwom narodowym ma ona przywrócić funkcje głównego podmiotu zarządzającego gospodarką i polityką. Przywódcy chińscy sięgają po te idee celowo, po to aby zbudować alternatywny dla liberalno-demokratycznego, porządek globalny (Leonard, 2009: 24).

Nie ulega więc żadnej wątpliwości, że na przestrzeni ostatnich kilku dekad, ChRL obok Stanów Zjednoczonych i Unii Europejskiej stała się wiodącą globalną potęgą gospodarczą i handlową. Nieprawdopodobnego wręcz przyspieszenia nabrał wzrost gospodarczy, modernizacja technologiczna i konkurencyjność. Analitycy sytuacji rozwojowej podkreślają fenomen trwałości wyjątkowo wysokiego tempa wzrostu PKB w niemal czterdziestoletnim już okresie transformacji. Do roku 2008 średnio było ono rzędu 10 procent rocznie, stanowiąc najwyższe tempo wzrostu PKB w tak długim okresie i w tak dużym kraju w świecie. Tempo wzrostu PKB w latach 1978-2008 było wyższe niż osiagane przez Japonię i inne „azjatyckie tygrysy” z Azji Południowo-Wschodniej w okresie ich powojennego skokowego rozwoju. Charakterystyczną cechą rozwoju ChRL jest trwale wysoki udział inwestycji i eksportu w relacji do PKB. Problemem pozostaje wciąż bardzo niski udział konsumpcji w relacji do PKB, rosnące rozwarstwienie dochodowe, dysproporcje w rozwoju regionalnym, wszechobecna korupcja i rosnące po 2008 r. bezrobocie. Nie bez znaczenia pozostają też inne bariery rozwojowe. Wzrost znaczenia ekonomicznego w świecie, czyli ,globalizacja dokonywana na chińskich zasadach" prowadziła do znacznie większego uzależnienia od sytuacji na światowych rynkach i „efektu domina”, czego dowiódł kryzys finansowy na rynku amerykańskim, który w sferze gospodarki realnej był wyraźnie odczuwalny w ChRL.

\section{STRATEGIE I CZYNNIKI WZROSTU GOSPODARCZEGO I EKSPANSJI CHRL W ŚWIECIE}

Czynniki budzącego podziw wzrostu gospodarczego i ekspansji handlowej ChRL w świecie są wielorakie i zmienne w czasie. Najczęściej wymienia się wśród nich, filozoficzno-religijny system konfucjanizmu wsparty elementami taoizmu, umiejętność twórczego korzystania z dorobku innych gospodarek (naśladownictwo uczciwe lub nieuczciwe) pragmatyczne, dalekowzroczne, strategiczne i naukowe myślenie o rozwoju kraju, a także umiejętność stopniowej, spokojnej realizacji celów (gradualizm działań). W ostatnich latach przyjął on formułę pokojowego wzrostu i pokojowego rozwoju (ang. peaceful growth/peaceful rising), modelu harmonijnego spoleczeństwa 
oraz strategii międzynarodowej ekspansji handlowej i inwestycyjnej, zwanej Going Global (Go Global). Rynek chiński jest przy tym dość trudny do zdobycia dla inwestorów zagranicznych. Obok bariery językowej bardzo często pojawiają się liczne bariery obyczajowe i kulturowe, począwszy od znaczenia symboli, gestów i prowadzenia rozmowy, aż po odmienności w zarządzaniu pracownikami. Jak twierdzi M. Kłaczyński z LL. M. Harvard - ponad połowa zachodnich inwestycji w ChRL kończy się niepowodzeniem, mimo że wolny rynek i otwarcie na współpracę z zagranicznymi przedsiębiorcami są w tym kraju dobrze ugruntowane. Przyczyny niepowodzeń biznesowych przedsięwzięć w Chinach leżą więc gdzie indziej. Jest to przede wszystkim bariera kulturowa $\mathrm{w}$ kontaktach $\mathrm{z}$ chińskimi przedsiębiorcami (obyczaje, tradycje i strategie negocjacyjne), nieuczciwość i nielojalność lokalnych partnerów (niedostateczna ochrona tajemnicy przedsiębiorstwa i zachodnich technologii) oraz bariera związana z nieznajomością i stronniczością lokalnego prawa.

Strategie ,pokojowego wzrostu” z 2003 r. i ,pokojowego rozwoju” z roku 2004 podkreślają, że rosnące w siłę Chiny mają wyłącznie pokojowe zamiary i nie popełnią historycznych błędów Niemiec, Japonii i ZSRR. Nie będą dążyły do rozwiązań siłowych i kontestacji porządku międzynarodowego, a ich celem jest wzrost w pokoju (ang. rise in peace) metodami pokojowymi (ang. rise peacefully). Promowana od 2006 r. przez KPCh koncepcja harmonijnego świata zakłada oparcie porządku światowego na zasadzie multilateralnego podejmowania decyzji, współpracy między państwami w ramach obustronnych korzyści (zasada win-win) oraz dążenie do równowagi sił w kontekście globalnym. Idea ta stworzona została jako alternatywa dla hegemonii amerykańskiej. Odwołuje się do konfucjańskiej koncepcji harmonii i wynikającej zeń delegitymizacji konfliktu i ma na celu kreowanie alternatywnych stosunków międzynarodowych, opartych na wartościach harmonii, równowagi, zgody i pokoju oraz łagodzeniu obaw świata przed szybkim wzrostem znaczenia Chin. Uzasadnieniem dla zwiększonej obecności ChRL ma być zobowiązanie do ,aktywnego udziału w sprawach międzynarodowych i wypełniania zobowiązań międzynarodowych oraz współpracy z innymi państwami na rzecz budowy sprawiedliwego i racjonalnego, nowego, międzynarodowego porządku politycznego i gospodarczego". Nowa strategia służyć ma poprawie wizerunku Chin, kreujących się na odpowiedzialnego partnera, którego celem jest działanie na rzecz globalnego i regionalnego ,pokoju, dobrobytu i harmonii” (Puślecki, Walkowski, Szymczyński, 2011: 199).

Wyrazem integracji ChRL z gospodarką światową stał się wzrost chińskich BIZ za granicą. Ten stosunkowo nowy trend ma związek z polityką rządu opartą na strategii Go Global, przedstawionej w 2001 r. Strategia zakłada pomoc państwa dla chińskich przedsiębiorstw w inwestowaniu za granicą, a jako najważniejsze dziedziny globalnej ekspansji wymieniała: tworzenie działalności produkcyjnej, eksploatację surowców wspólnie z lokalnymi partnerami, realizację międzynarodowych kontraktów na projekty inżynieryjne oraz wzrost eksportu chińskich usług. Wsparcie finansowe dla globalnej ekspansji chińskich przedsiębiorstw ma głównie postać subsydiów na pokrycie kosztów inwestycji oraz preferencyjnego oprocentowania kredytów ${ }^{10}$ (Gradziuk, Szczudlik-Tatar, 2012: 55).

${ }^{10}$ Pomocy finansowej przedsiębiorstwom chińskim realizującym strategię „Go Global” udzielają dwa banki: China Development Bank oraz China Exim Bank. Pomoc rządu dla chińskich przedsiębiorstw w globalnej ekspansji polega także na ich promowaniu w trakcie oficjalnych wizyt 
W okresie, gdy na rynkach światowych doszło do kryzysu finansowego 2008+, władze chińskie zmodyfikowały nadrzędny cel swej transformacji i reform, jakim było świadome budowanie statusu mocarstwa, optując za szeroko promowanym sloganem „renesansu chińskiej nacji”. Punkt ciężkości, jeśli chodzi o adresatów reform, którymi przez trzy dekady byli jedynie obywatele Chin kontynentalnych, został przesunięty w innym kierunku. Obecnie ich adresatem są wszyscy Chińczycy, gdziekolwiek się znajdują, zarówno ci od pokoleń żyjący w ChRL, jak i ci, którzy niedawno powrócili do macierzy (z Hongkongu czy Makao). Zaliczane są do nich także te osoby, które znajdują się poza jurysdykcją Chin kontynentalnych (Tajwan i rozległa chińska diaspora, w samej Azji Południowo-Wschodniej szacowana na ponad $35 \mathrm{mln}$ osób). Hasło „renesansu chińskiej nacji” bezpośrednio łączy się z innym, fundamentalnym zadaniem rządu w Pekinie, a mianowicie koniecznością re-unifikacji z Tajwanem.

Używane do dziś pojęcia pokojowego wzrostu i pokojowego rozwoju, z czasem coraz częściej zaczęto uzupełniać innym terminem - rozwój naukowy (chiń. kexue fazhan). Oba do państwowej i partyjnej strategii wprowadzono na XVIII zjeździe KPCh w listopadzie 2012 r. Przesłanie z niego płynące jest takie, że ChRL w swych zachowaniach nie kieruje się przesłankami czy uprzedzeniami ideologicznymi, lecz prowadzą swą politykę w oparciu o najnowsze badania naukowe. Równocześnie nie mają żadnych rewizjonistycznych zamiarów i nie chcą zmieniać istniejącego porządku w świecie. Podtrzymują zasady pokojowego współistnienia, preferując politykę nieingerencji w sprawy wewnętrzne oraz opowiadają się za multilateralizmem, czyli budową kilku głównych ośrodków władzy na świecie, z których oczywiście wiodącym mają być Chiny. ChRL dała tym samym światu wyraźny sygnał: tak-jesteśmy otwarci na wspótpracę, ale globalnej hegemonii amerykańskiej się sprzeciwiamy, podobnie jak wszelkim ingerencjom w sprawy wewnętrzne innych państw. Podtrzymuje przy tym zasady pokojowego współistnienia, dając do zrozumienia, że nie powieli zachodniego modelu liberalnej demokracji (Gittings, 2010; Pawlak, 2013).

\section{ISTOTA CHIŃSKIEGO MODELU ROZWOJU}

James Mann w pracy pt. The China Fantasy. Why Capitalism Will Not Bring Democracy to China pisze, że zrozumienie chińskiej strategii rozwoju i modelu życia wydaje się być niezbędne także w kontekście ogromu stereotypów związanych z ChRL.

państwowych, włączaniu negocjacji kontraktów na określone projekty do agendy współpracy międzyrządowej, tworzeniu bazy danych na temat warunków prowadzenia działalności gospodarczej w danym kraju czy na doradztwie dla firm planujących inwestycje zagraniczne. Oprócz rządu centralnego również władze lokalne starają się wspierać zagraniczną aktywność chińskich przedsiębiorstw. Priorytetem chińskiego rządu jest wykreowanie tak zwanych globalnych czempionów, czyli dużych międzynarodowych korporacji o globalnie rozpoznawalnej marce, które będą zdolne do rywalizacji na rynku międzynarodowym z najważniejszymi amerykańskimi, europejskimi, japońskimi czy koreańskimi korporacjami transnarodowymi. Szczególne nadzieje pokłada się w przedsiębiorstwach, które odniosły sukces na rynku wewnętrznym i były w stanie eksportować konkurencyjne produkty. Dzięki strategii przedsiębiorstwa typu Haier, Huawei, Lenovo, Petrochina czy Sinopec potrafiły zwiększyć skalę swojej działalności, podnieść jakość, zwiększać zyski i stać się rozpoznawalną marką globalną. 
Trudno nie przyznać mu racji. W kontekście ważnych wydarzeń światowych odbywających się w ChRL (Igrzyska Olimpijskie, Targi Expo) media o globalnym zasięgu stale wyciagają na światło dzienne te same stereotypowe frazy o Chinach. Wykorzystując tytuły filmów, słynne wydarzenia lub historyczne cytaty, obraz Chin budują na takich skojarzeniach jak Chiński syndrom, Ostatni cesarz, Dlugi Marsz, Wielki Mur Chiński, Rewolucja kulturalna, Wielki skok naprzód, Śpiqcy olbrzym się budzi, Przyczajony tygrys, ukryty smok, Marco Polo, Powstanie bokserów. Stacje radiowe i telewizyjne do podkładu swych relacji zazwyczaj wykorzystują wówczas tradycyjną chińską muzykę, a programy telewizyjne poświęcone Chinom, zazwyczaj od lat pokazują te same widoki, a wśród nich smoki, lwy, Wielki Mur, chińską kaligrafię, pandy, terakotową armię z Xian itp. Ukazane są też symbole Chin nowoczesnych: młodzi Chińczycy w klubach tanecznych czy przed komputerami, korki uliczne, światła Szanghaju nocą. Wiele z tych medialnych klisz czyni Chiny i Chińczyków bardziej „egzotycznymi”, sprawiając, że wydają się one bardziej tajemnicze, odległe i trudniejsze do zrozumienia niż są w rzeczywistości.

Nagłaśniane od lat chińskie sukcesy gospodarcze (ale i coraz częściej podkreślane liczne koszty społeczne i środowiskowe) spowodowały, że w ostatnich latach na znaczeniu nabrała debata na temat potencjalnej uniwersalności chińskiego modelu rozwoju. Model ten ostatnimi laty stał się bardzo atrakcyjny dla wielu rządów, głównie słabiej rozwiniętych państw w świecie, szczególnie w Afryce, Ameryce Łacińskiej i Azji Centralnej, gdzie bardzo aktywne są chińskie spółki i dyplomaci. Trwający od 2008 r. globalny kryzys finansowy i ekonomiczny w wielu regionach świata podważył bowiem zaufanie do anglosaskiego modelu gospodarki wolnorynkowej i towarzyszącej mu ideologii neoliberalnej. Szybkość, z jaką ChRL przeszła ze statusu biednego kraju rolniczego do globalnej potęgi gospodarczej, budzi podziw. Przedstawiciele Wietnamu, Birmy, Kambodży, Syrii czy Iranu, z uwagą studiują chińską drogę rozwoju, zastanawiając się, czy i jakie jej elementy można zastosować. $Z$ badań wynika, że w wielu innych państwach opinie o chińskim modelu są pozytywne. W Nigerii i Pakistanie tak oceniało go 85\% badanych, a w Indonezji i w Rosji około $60 \%$. Także w Unii Europejskiej trwa debata na temat kształtowania prawidłowych relacji z Chinami i oceny chińskiej formuły rozwojowej. W związku z niemal powszechną krytyką wolnorynkowego modelu opartego na tzw. konsensusie waszyngtońskim (ang. Washington Consensus), w 2004 r. J. Cooper Ramo - wykładający w Chinach ceniony amerykański analityk i były wydawca magazynu „Time” - chcąc pokazać specyfikę i oryginalność chińskiego podejścia do rozwoju skonstruował model, określając go mianem konsensusu pekińskiego (ang. The Beijing Consensus) ${ }^{11}$.

${ }^{11}$ Konsensus waszyngtoński to dokument przedstawiony w 1989 r. w Waszyngtonie przez dyrektora Instytutu Gospodarki Światowej Jamesa Williamsona, który stał się kanonem neoliberalnych reform gospodarczych państw przechodzących transformację ustrojową. Są to zalecenia organizacji międzynarodowych (MFW, BŚ) służące dynamizacji rozwoju poprzez reformy rynkowe i szerokie otwarcie gospodarki na procesy globalizacji. Opiera się on, w dwóch wersjach, na dziesięciu dyrektywach zalecających m.in. dyscyplinę fiskalną (niskie deficyty budżetowe i wskaźniki inflacji), prorozwojowe priorytety w wydatkach budżetowych (edukacja, nauka, służba zdrowia, infrastruktura), obniżenie podatków dochodowych na rzecz wzrostu znaczenia podatków pośrednich, liberalizację handlu, rynków finansowych i przepływów kapitałowych typu BIZ, prywatyzację przedsiębiorstw państwowych, deregulację rynków z wyjątkiem sfer związanych z bezpieczeństwem 
Chińscy przywódcy od kilku dekad realizują to, co niektórzy naukowcy i komentatorzy na Zachodzie nazywają konsensusem pekińskim, czyli nowy model rozwoju, w którym wolnorynkowy rozwój gospodarczy „bierze rozwód” z liberalizacją sfery politycznej, a kapitalizm oddzielany jest od demokracji, nabierając cech autorytarnych. Bez względu na to jak model ów nazwiemy, należy przyznać, że mimo wszystkich swych oczywistych braków i zastrzeżeń KPCh zdołała w ciagu niemal czterech dekad doprowadzić do szybkiego wzrostu gospodarczego w warunkach dość stabilnego systemu politycznego oraz przybliżyła Chiny do zbudowania xiaokang shehui, tzn. „umiarkowanie bogatego społeczeństwa”, do czego dążył Deng Xiaoping. Obietnica ta skłoniła wielu Chińczyków do zawarcia swego rodzaju niepisanej umowy z partią, która przyjęła formułę: ,jeśli wolno będzie się nam bogacić i dążyć do lepszego standardu życia, i jeśli kraj nasz będzie coraz bardziej zmierzał w kierunku dobrobytu i mocarstwowej pozycji w świecie, to nie będziemy próbowali podważać rządów autorytarnych" (Schell, Delury, 2013: 74).

Chociaż słowa „szacunek" $\mathrm{i}$,status” bezpośrednio razem nie pojawiają się w starożytnej parze znaków fuqiang (富强), która oznacza „bogactwo i potęga”, to w dążeniu Chin do realizacji tych dawno postawionych sobie celów są bardzo wyraźnie widoczne. Dążenie do dobrobytu i mocarstwowości ma swoje korzenie w upokorzeniach doznanych w XIX w. od potęg imperialnych. Aby jednak zdobyć ogólnoświatowe ,uznanie" (chin. zunzhong) - termin notorycznie używany w języku chińskiej dyplomacji - naród musi nie tylko osiągnąc dobrobyt i potęgę, ale także kultywować inne cechy, które zdołają wywołać taki podziw w świecie (ibid.).

W opinii B. Góralczyka, cenionego polskiego naukowca i dyplomaty, Chińczycy nigdy terminem Konsensus pekiński nie posługiwali się. Owszem odrzucili oni popularyzowany przez USA i MFW neoliberalny konsensus waszyngtonski, ale też własnej formuły rozwojowej konsensusem pekińskim nie nazywali. W ChRL już w 2005 r. renomowana Chińska Akademia Nauk Społecznych zorganizowała na ten temat specjalne seminarium i odrzuciła koncept jako „nieprzystający do chińskiej rzeczywistości”. Przez trzy dekady ,epoki reform i otwarcia na świat” Chiny wypracowały własny model rozwojowy, na podstawie którego to jego apologeci zaczęli mówić o chińskim śnie (chiń. Zhongguo Meng), który miałby w niedalekiej przyszłości zastąpić w świecie dotychczasowy, mityczny amerykański sen o potędze i dobrobycie - American Dream. Zgodnie z tą optyką świat skazany jest na chińską dominację, która jednak będzie wyraźnie inna od amerykańskiej. Ma być ona oparta nie tyle na sile i mocy militarnej, ile na „dobrym przykładzie”, chińskim wzorcu cywilizacyjnym (chiń. wang dao) i miękkiej sile (Góralczyk, 2010: 90).

Termin Beijing Consensus - nadal popularny jest jednak na Zachodzie, głównie za sprawą prac S. Halpera. Według tego cenionego autora chiński model rozwojowy jest wyrazem ,unikalnego charakteru chińskiej kultury (konfucjańskie zasady), demografii (ponad 1,3 mld ludności) filozofii rządzenia i relacji między rządzącymi i rządzonymi

narodowym, ochroną środowiska i nadzorem nad instytucjami finansowymi, niezależność Banku Centralnego, silny aparat skarbowy, niezależne i skuteczne sądownictwo, dobrze funkcjonujące agencje promujące przedsięwzięcia rozwojowe. Por. Konsensus Waszyngtoński, Encyklopedia Zarządzania - www.mfiles.pl. Szerzej zob.: J. Osiatyński (2006), Finanse publiczne-ekonomia i polityka, Warszawa; S. Owsiak (2005), Finanse publiczne - teoria i praktyka, Warszawa. 
(system wspólnych wartości). Autor ten podkreśla wielkie umiejętności przywódców ChRL korzystania z doświadczeń wielu krajów i wyciagania wniosków z ich sukcesów i niepowodzeń. Strategia rozwoju Chin jest zatem stale dostosowywana do zmieniających się warunków wewnętrznych i zewnętrznych (Halper, 2010: 39; Jacques, 2012: 58).

Podstawowe elementy chińskiego paradygmatu rozwojowego wg B. Góralczyka to: 1) pragmatyczne, nieideologiczne podejście do reform; 2) stopniowe, ostrożne dawkowanie zmian; 3) elastyczność w prowadzeniu zmian, stałe eksperymentowanie i dostosowywanie się do szybko zmieniających się warunków i okoliczności, tak wewnątrz kraju, jak na rynkach światowych; 4) trzeźwa ocena własnych możliwości i szans, połączona z chłodną pragmatyczną kalkulacją wyłaniających się nowych okoliczności na stale i szybko zmieniającej się arenie międzynarodowej doby globalizacji; 5) prowadzenie procesu rozwojowego przez państwo oraz zachowanie w wybranych, strategicznych dziedzinach interwencjonizmu państwowego przy uwolnionym ryn$\mathrm{ku}$; 6) otwarcie własnego rynku na obcy kapitał, jednakże przy stałym preferowaniu kapitału własnego; 7) łączenie własnej transformacji z procesami globalizacyjnymi; 8) prymat autorytaryzmu i rynku nad demokracją oraz kolektywne podejmowanie decyzji; 9) powrót do korzeni, a przede wszystkim patriarchalnego i hierarchicznego z ducha konfucjanizmu; 10) stała rotacja rządzących kadr i należyte ich, praktyczne przygotowanie, a tym samym nawrót do zasad merytokracji; 11) odrzucenie wzorców zachodnich przy równoczesnym obserwowaniu zachodzących na świecie zmian i korzystaniu z tego, co mogłoby być dla państwa pomocne lub przydatne.

W gospodarce chińskiej korzysta się z wypracowanej jeszcze w XIX stuleciu zasady brzmiącej „to, co chińskie, jest istotne, to co zachodnie - wspomagające”. Przyciągnięto kapitał zagraniczny i know-how, ale w sposób selektywny, zgodny z własnym interesem i nie naruszając chińskich rozwiązań systemowych. Aktualnie zamiast eksportu i inwestycji podstawowym motorem napędzającym rozwój kraju ma się stać konsumpcja wewnętrzna i nowoczesne technologie. Chiny mają więc przejść w fazę innowacyjnej produkcji, a Chińczycy więcej kupować, najlepiej chińskich produktów. Odbudowana ma być też sieć świadczeń socjalnych i zdrowotnych, a niszczone dotychczas środowisko naturalne ma być zastąpione ,zieloną gospodarką”. Pod rządami piątej generacji przywódców, do roku 2023 ChRL ma wyprzedzić Stany Zjednoczone i stać się pierwszą gospodarką w świecie. Do tego czasu ma też dojść do „wielkiego renesansu narodu chińskiego", którego jednym z kluczowych elementów ma się stać wspomniane „pokojowe zjednoczenie z Tajwanem” (Góralczyk, 2010: 92).

Jak dowodzi A. Bolesta ,chiński autorytaryzm”, określany przez Chińczyków mianem demokracji kolektywnej bądź demokracji chińskiej, jest ustrojem endemicznym i stanowi oddzielny i unikatowy w świecie model rozwojowy. Według tego autora, w przypadku Chin państwo było i pozostanie motorem rozwoju i przemian systemowych. To ono budowało i buduje nadal system ekonomiczny oparty na własności kolektywnej. Także struktury społeczne wytworzone w ChRL mają charakter kolektywny, co powoduje powstawanie kultury, odrębnej od indywidualistycznej dominującej na Zachodzie. Reformy systemowe i polityka rozwojowa w ChRL nie byłyby przy tym możliwe bez silnego przywództwa. Pozycja lidera, w szczególności charyzmatycznego przywódcy i dobrego zarządcy, pozostaje silnie zakorzeniona w chińskiej kultu- 
rze i tradycji, wywodząc się z filozofii konfucjańskiej. Chińczycy przywiązują wielką wagę do nakazów i poczynań osoby rządzącej, jeśli takowa cieszy się powszechnym szacunkiem. Przewodniczący Deng uważał, że transformacja musi zachodzić w stabilnym środowisku, zgodnie z chińskim mottem głoszącym, że „stabilność ma najważniejsze znaczenie", gdyż prawdopodobieństwo chaosu jest nadzwyczaj wysokie (Bolesta, 2006).

W opinii A. Bolesty, KPCh zawsze charakteryzował wysoki poziom personalizacji władzy. Skoro silne przywództwo traktowano jako ważny element chińskiego mechanizmu ustrojowego, a wynikało to z historii, filozofii, tradycji i kultury - to partia komunistyczna będąc wiodącą siłą polityczną w kraju i jedyną dzierżącą realną władzę, musiała charakteryzować się tą cechą. Siła państwa chińskiego leży więc nie tylko w samym dostosowaniu aparatu państwowego do nowych warunków społeczno-gospodarczych, ale też w możliwościach szybkiego wprowadzania nowych regulacji. Autorzy chińskich reform mogą realizować politykę długookresową. Nie są oni co kilka lat odpowiedzialni przed społeczeństwem w ramach aktu wyborczego, jak ma to miejsce w przypadku wielu państw liberalnych i demokratycznych. Silne państwo musi posiadać wystarczającą władzę i jej atrybuty (w tym media, sądy, aparat represji), aby przeprowadzać trudne, ale często niezbędne zmiany społeczno-ekonomiczne. Potwierdzał to dynamiczny rozwój gospodarczy i procesy modernizacyjne, jakie miały miejsce w warunkach ustroju autorytarnego w Korei Południowej, na Tajwanie i w Singapurze (ibid.).

Z kolei H. Chołaj pisze o „chińskim modelu socjalizmu”, czyli rodzaju gospodarki sterowanej przez państwo, charakteryzującej się scentralizowaniem i kontrolą polityczną. W jego opinii Chińczycy tworzą zupełnie nowy rozdział swej historii - rozdział oświeconego i elastycznego totalitaryzmu, który adaptuje do innych celów strategicznych niektóre rozwiązania demokracji, kapitalizmu, nie przyjmując jednak ich liberalnej istoty. W chińskim modelu rozwojowym decydującą rolę odgrywa trójkąt: autokracja - technokracja - planowanie strategiczne. Autor ten cytuje przy tym innych specjalistów z tej dziedziny. I tak zdaniem A. Zorskiej model chińskiego systemu kapitalistycznego można określić mianem „kapitalizmu hybrydowego”, w którym wymieszano i połączono wiele elementów i rozwiązań, jakie stosowane były w przeszłości (w tym elementy związane z dziedzictwem kulturowym) z rozwiązaniami charakterystycznymi dla współczesnej gospodarki. G. Kołodko mówi o chińskim wydaniu „kapitalizmu państwowego”, podkreślając, że sami Chińczycy terminu tego nie używają, preferując określenie „socjalizm rynkowy”. Jednocześnie autor ten podkreśla, że sukces ChRL spowodował, że świat jest zafascynowany sukcesami gospodarczymi nieortodoksyjnej szkoły ekonomicznej, która wyrasta z założeń koncepcji socjalizmu o chińskiej specyfice. Przedstawiciele ChRL - co ważne - nie uważają, że ustrój ich państwa może nadawać się do adaptacji przez jakiekolwiek inne (Chołaj, 2014: 34).

Z kolei R. Pyffel na łamach opiniotwórczego portalu Polska-Azja dowodzi, że ChRL jest największym wyzwaniem dla pogrążonego po $2008 \mathrm{r}$. w kryzysie świata demokratycznego. Państwo Środka stworzyło własny model rządów, ostentacyjnie odżegnując się od demokracji liberalnej i lekceważąc krytykę ze strony Zachodu. Władze podkreślają, że system demokracji liberalnej jest nieatrakcyjny i sprzeczny z chińską tradycją wyrosłą na konfucjanizmie, a więc na hierarchicznych relacjach między 
władzą (Ojcem) a społeczeństwem (dziećmi). Wg tego znanego analityka, chiński system polityczny stale ewoluował, ale co do istoty się nie zmienił. Jego specyfikę najprościej określić można jako połączenie kapitalistycznej gospodarki z autorytarną władzą. Chiński model - w jego opinii - wraz z kryzysem zachodniej demokracji staje się coraz silniejszy. Im bardziej widoczne dysfunkcje tej ostatniej, tym bardziej widoczne stają się zalety konsensusu pekińskiego. Model ten może więc stać się alternatywą dla liberalnej demokracji poza Chinami, choć sami Chińczycy potencjalnym zainteresowanym, przynajmniej oficjalnie, odradzają jego stosowanie, adaptację czy naśladownictwo. Odbywa się to zgodnie z zasadą „,nie chcemy waszego systemu, bo jesteśmy inni, ale dlatego też odradzamy wam kopiowanie naszych rozwiązań". Ideologia odgrywa w dzisiejszej polityce zagranicznej ChRL rolę marginalną. Liczy się pragmatyzm i biznes. Pozostaje jednak pytanie, czy po pewnym czasie, kiedy będzie już wystarczająco silna, aby otwarcie rzucić wyzwanie Zachodowi, ChRL nie zmieni taktyki i nie zacznie narzucać innym państwom własnych rozwiązań. Według R. Pyffla, model chiński może być inspirujący, ale głównie dla biedniejszych państw pozaeuropejskich. W Europie będzie on o wiele trudniejszy do zastosowania, a w wielu elementach wręcz niemożliwy. Pewne elementy strategii chińskiej takie jak kilkuletnie, planowe i stopniowo wprowadzane zmiany są przy tym możliwe do selektywnego wykorzystania w państwach członkowskich UE jak i na poziomie ponadnarodowym w zintegrowanej Europie (Pyffel, 2013).

Chiny począwszy od $1978 \mathrm{r}$. stopniowo, ,przechodziły przez rzekę i ostrożnie stąpały po kamieniach", dążąc do realizacji modelu gospodarki wolnorynkowej we własnym, unikatowym wydaniu. Ważną i trudną do przecenienia rolę w tej strategii odgrywają elementy miękkiej sity oraz wartości azjatyckie. Wśród narzędzi kulturowych wykorzystywanych przez Chińczyków na plan pierwszy wysuwa się szeroko zakrojona akcja propagandowa $\mathrm{w}$ ramach dyplomacji publicznej, której głównym celem jest przekonanie światowej opinii publicznej, że rosnące w potęgę Chiny nie stanowią zagrożenia. Przekaz ten jest wysyłany na wiele różnych sposobów: przez publiczne wystąpienia polityków, działania dyplomatów, dziennikarzy, chińskich naukowców i studentów. Jednocześnie obserwować można rosnącą ekspansję międzynarodową chińskich mediów. Agencja informacyjna Xinhua od dawna działa na skalę globalna, konkurując z agencją Reuter. Powstają zagraniczne wydania dziennika „Peoples Daily” i „China Daily”, a chińska telewizja CCTV wciąż zwiększa krąg swoich odbiorców na świecie i tworzy kanały obcojęzyczne (ibid.). W ramach chińskiej polityki soft power wzrastają wpływy kulturowe i ideologiczne ChRL w świecie, a jednym z tego przejawów jest promocja chińskiej kultury i języka. Centralną rolę odgrywają tu setki rozsianych na wzór British Council po całym świecie i wzbudzające coraz więcej kontrowersji, Instytuty Konfucjusza oraz klasy konfucjańskie w szkołach średnich. Elementem soft power jest też efektywne wykorzystanie licznej diaspory chińskiej, która w istotny sposób kształtuje wizerunek państwa i może być znakomitym propagatorem kultury, stanowiąc ułatwienie w nawiązywaniu relacji handlowych czy inwestycyjnych. ChRL intensywnie rozwija też ofertę stypendialną dla zagranicznych naukowców, artystów i studentów. Tworzone są specjalne programy, zachęcające, głównie finansowo, wykładowców z tzw. świata Zachodu do przenoszenia się na chińskie uniwersytety. Szeroka kampania marketingowa skierowana jest 
również do młodzieży z państw rozwijających się. Kolejny element to organizacja wielkich imprez sportowych i kulturalnych. Ważnym elementem chińskiej polityki kulturalnej i dyplomacji publicznej była organizacja Igrzysk Olimpijskich w Pekinie w 2008 r. oraz wystawa Expo w Szanghaju dwa lata później. W szczególności igrzyska, zorganizowane $\mathrm{z}$ rozmachem i profesjonalnie stały się okazją do prezentowania ChRL jako państwa otwartego (slogan Open China) oraz przykładającego wagę do zrównoważonego rozwoju i ochrony środowiska (slogan Green Games) (Kamiński, 2014; Kamiński, 2014b).

Rolę wartości azjatyckich podkreśla z kolei M. Meyer. W jego opinii model rozwojowy państw Azji Południowej i Wschodniej jest pochodną odkrycia przez M. Bonda oraz G. Hofstede zestawu cech osobowych, które są pozytywnie skorelowane ze wzrostem gospodarczym państw tego regionu. Jest to typowe dla „konfucjańskiego dynamizmu". Można do nich zaliczyć: oszczędność i zapobiegliwość, upór (wytrwałość), poczucie wstydu, kształtowanie stosunków międzyludzkich, poszanowanie tradycji, odwzajemnianie pozdrowień (oraz prezentów i przysług), troska o zachowanie twarzy, ustatkowanie i równowagę. W latach 90 . XX wieku, w dyskursie publicznym szerzej pojawiło się określenie „,wartości azjatyckie”. Jego twórca, Lee Kuan Yew, sukces gospodarczy Singapuru przypisywał faktowi, że jego społeczeństwo ciężko pracuje, jest zdyscyplinowane i oszczędne, charakteryzuje się silnymi więzami rodzinnymi i odpowiedzialnością za członków rodziny. W latach 80 . XX wieku zachęcał on rodziców do przekazywania tych wartości swoim dzieciom, przypominając, że sukces tego państwa pochodzi „,z silnego ducha pracowitości Azjatów oraz z wagi, jaką przywiązują oni do związków rodzinnych i obowiązków na linii rodzice-dzieci". Podstawą sukcesu jest prymat rodziny i społeczności nad prawami jednostki, prymat zgody nad różnicą zdań, prymat dyscypliny nad liberalizmem. Zgodnie z tą wykładnią Azjaci kładą nacisk raczej na społeczność niż na jednostkę, przedkładają porządek i harmonię nad osobistą wolność, nie oddzielają religii od innych sfer życia, cechuje ich oszczędność i gospodarność, cenią ciężką pracę, szanują politycznych przywódców i rodzinną lojalność (Konfucjanizm, 2013).

W Chinach potrzebą elementarną jest porządek. Potrzeba ta zrodziła się w kontekście trwających setki lat wojen i do dziś pozostała żywa, stanowiąc ostrzeżenie przed „nie-porządkiem i chaosem” oraz ,utratą twarzy”. Porządek, zasadzający się na przewidywalności, stanowi wartość samą w sobie, stabilność jest bowiem podstawowym warunkiem harmonijnego (chiń. hepingde) współżycia. W społeczeństwie rządzącym się zasadami metakonfucjanizmu nie ma alternatywy dla harmonii. Wending (pol. stabilność) stało się jednym z ulubionych przesłań Deng Xiaopinga wdrażanych do dziś (ibid.; Weggel, 2006) ${ }^{12}$.

${ }_{12}$ M. Meyer podkreśla, że w chińskiej kulturze, jak i w działalności gospodarczej, reputacja i pozycja społeczna konkretnej osoby zależy od „zachowania twarzy” (chin. mianzi). Jest to pojęcie zbliżone do tego, czym jest w Europie prestiż bądź szacunek, z jednym wszak wyjątkiem. „Twarz”, podobnie jak pieniądze, można stracić, zyskać, nadać ją lub odebrać. Powodami do szczególnego szacunku (a więc „,nadania twarzy”) może być zasobność, inteligencja, atrakcyjność, umiejętności, pozycja społeczna, czy dobre guanxi (szczególnie z wpływowymi osobami). Spowodowanie, iż w czasie negocjacji handlowych partner ,straci twarz” (poprzez np. przyjazd na rozmowy osoby niższej rangą niż zapowiadana, bądź próby rozwiązywania dylematów przy stole negocjacyjnym wybuchami gniewu) może przynieść nieodwracalne skutki. Jedną z żelaznych zasad powinno być więc unikanie publicznego krytykowania 
Recepta na sukces gospodarczy sprowadza się do wypracowanej przez lata skomplikowanej strategii rozwojowej, określanej jako ,3+3+6”. Składa się ona z trzech reguł ogólnych (równowaga, efektywność, eksport), służących uzyskaniu fuqiang, czyli „dobrobytu i siły"; trzech inwestycji (w gospodarkę, w ludzi i w środowisko naturalne) oraz z sześciu klasycznych reguł zachowania - cnót gospodarczych (wydajna praca, pilność, oszczędność, przedsiębiorczość ze skłonnością do ryzyka, brak tematów tabu i korporacjonizm). W dziedzinie handlu zagranicznego maksyma ,3+3+6" do kryzysowego 2008 r. sprowadzała się do żądania, aby Chińczycy produkowali możliwie dużo, a nieChińczycy możliwie dużo konsumowali. Najbardziej doniosła gospodarczo jest jednak szósta cnota Chińczyków, a mianowicie korporacjonizm związany z umiejętnością tworzenia sieci interesów i zręcznością w „snuciu nici stosunków/układów”, znajomości i zależności, niestety często korupcjogennych (chiń. guanxi). Guanxi to pochodna triady: trwanie - wysiłek - zaufanie. Inaczej niż na Zachodzie nie ograniczają się do wybranych sytuacji życiowych czy określonych działań, lecz - o ile to możliwe - budowane są przez całe życie, stanowią niejako „dobra trwałe”. Stanowią one i wartości same w sobie i dla przeciętnego Chińczyka mają takie samo znaczenie, jak dla Europejczyka indywidualność i autonomia osobista (Tomalin, Nicks, 2014: 39).

W opinii Chińczyków cywilizacja chińska w porównaniu z Zachodem była od wieków bardziej zaawansowana, szczególnie w sferze sztuki i nauki. Nic więc dziwnego, że obywatele tego kraju wciąż wierzą w jego wyższość. Chińczycy cenią sobie etykę pracy, zasady konfucjanizmu, siłę rodziny oraz szczerość. Doceniają cierpliwość, elokwencję, przystosowalność, pokorę oraz wytrwałość. Nie lubią gwałtowności, impulsywności i złości czy ,tracenia twarzy” przed innymi ludźmi, nieskromności, braku szacunku wobec starszych i ekstrawagancji. Obowiązki, poświęcenie, łagodność oraz mądrość to inne cechy podziwiane przez Chińczyków. Ich zdaniem relacje są ważniejsze od zadań, a dążenie do cnoty uważają za istotniejsze niż poszukiwanie prawdy. Chińczycy robią interesy z ludźmi, a nie z instytucjami. Osobisty kontakt oraz lojalność są dla nich bardzo ważne. Cenią sobie szczerość ponad wszelkie inne wartości. I co kluczowe dla zrozumienia ich systemu aksjologicznego - praktykują guanxi - wdzięczność za wyświadczone przysługi (ibid.).

rozmówców przed ich kolegami bądź przełożonymi. W Chinach można więc komuś „dać twarz” lub „zabrać twarz”. Pod pojęciem „twarzy” kryje się nie fizyczny, lecz społeczny profil osoby. Dany człowiek nie jest bowiem w pierwszym rzędzie jednostką i indywidualnością, lecz członkiem grupy i musi się kierować kodeksem postępowania ściśle związanym z odgrywaną rolą społeczną. „Przywódcy” „daje się twarz", zapisując skrzętnie wszystkie jego wypowiedzi lub powtarzając nabożnie jego sformułowania. Traci on twarz, gdy słuchacz wzbrania się przed spełnieniem tych oczekiwań. U Chińczyków, którzy zawsze skazani byli na ścisłą współpracę, ciagłe „dawanie twarzy” sąsiadom, kolegom, bliskim stało się normą społeczną. Główną regułę gry obowiązującą w Chinach można by sformułować w sposób następujący: „Daj każdemu jego twarz, nie pozwól nikomu stracić twarzy, dbaj o zachowanie własnej twarzy". Inną zasadą chińskiego porządku jest pionowy układ więzi wspólnotowej. Gatunek homo hierarchicus nigdzie na świecie nie występuje w takim natężeniu, jak w społeczeństwach Chin, Japonii, Wietnamu i Korei. Utrzymywaniu porządku służy też surowe przestrzeganie etykiety. Spontaniczność to rzecz w Chinach zakazana. Można natomiast z Chińczykami łatwo znaleźć wspólny język, jeśli będziemy przestrzegać właściwych form, zachowywać się powściągliwie i w sposób, jakiego rozmówca od nas oczekuje. Ważnym elementem formalizacji rozmów jest użycie języka chińskiego. Przechodzenie z języka europejskiego na chiński jest w ChRL wyjątkowo mile widziane. Zob. również: Słowniczek pojęć, http://www.gochina.gov.pl/ (10.09.2016). 


\section{GUANXI JAKO KWINTESENCJA RELACJI SPOŁECZNYCH W CHINACH}

Guanxi stanowią najważniejszą konsekwencję chińskiej formacji wspólnotowej. Dla Chińczyków prowadzenie interesów to sprawa, która rozgrywa się między ludźmi, a nie między instytucjami. Zanim podejmie się pewne zobowiązania, ludzie muszą się więc poznać. Często, szczególnie starsze pokolenie Chińczyków, ceni sobie, aby partner handlowy czy inwestycyjny z Zachodu był polecony przez inną firmę. Kontaktów osobistych nie nawiązuje się więc przez internet. Partnerzy z Chin cenią sobie odbycie wielu rozmów, spotkań, również przy stole bankietowym, aby lepiej się poznać i utrwalić związki, które mają ugruntować wzajemne zaufanie. Europejczycy często opierają wybór partnera biznesowego na informacji z wiarygodnej instytucji bądź z bazy danych konkretnej branży. Chińczycy przed podjęciem konkretnych rozmów, zabiegają aby charakter współpracy miał wymiar znacznie bardziej personalny. Guanxi wymaga ciągłej pielęgnacji wzajemnych stosunków/relacji przez regularne wizyty, rytualizację ( $w$ formie uroczystości rodzinnych i firmowych), a przede wszystkim częste i udane bankiety. Do ich istoty należy staranny wybór restauracji, wyrafinowane menu, trącanie się kieliszkami i wznoszenie toastów za wspólną przyjaźn oraz „protokołowanie” ceremonii na filmach lub seriach zdjęć. Wszystko to należy do ceremoniału okazywania „przyjacielowi” szacunku i uwagi. W spotkaniach towarzyskich tematów zawodowych raczej się unika. W pierwszym rzędzie chodzi o pielęgnowanie kontaktów, które automatycznie przekładają się na sukcesy w pracy. Ważne jest też pośrednictwo konkretnej osoby, polecającej sobie strony. Rola takiej jednostki, zarówno na wstępnym etapie poznania się partnerów, jak i w czasie rozmów (szczególnie w momencie impasu) jest szczególnie istotna. Obcokrajowiec (nawet jeśli jest absolwentem sinologii) nie jest do końca w stanie określić gestu bądź prawdziwego (pozytywnego bądź negatywnego) odcienia znaczeniowego stwierdzeń typu ,wydaje się do zrealizowania” czy „wydaje się, że jest nieźle”. Zazwyczaj rolę osoby pośredniczącej (chiń. Zhongjian Ren) pełni więc Chińczyk (ibid.; Stowniczek pojęć).

Jak pisze David M. Lampton, Chińczycy tak bardzo są częścią różnych układów i relacji, leżących u podstaw ich specyficznego toku myślenia, że stworzyli nawet specyficzny język na opisanie tej sfery ludzkich dążeń: guanxi (relacje, związki, ang. relationships); lingdao guanxi (relacje między liderami, ang. leader relationships); yewu guanxi (relacje zawodowe lub konsultacyjne, ang. professional or consultative relationships); guanxiwang (sieć znajomości, ang. network of relationships); oraz guanxixue (nauka znajomości, ang. the study of relationships). Według Josepha Needhama chiński tok myślenia jest „organizmiczny” (organismic). Jest to pojęcie poznawcze, według którego myślenie nie jest linearne i opiera się na wzajemnych powiązaniach i wzajemnym oddziaływaniu. Dla Chińczyków, sieci powiązań funkcjonują w podlegającym ciagłym zmianom środowisku, w którym potrzeby, możliwości i intencje wszystkich stron nieustannie się zmieniają (Lampton, 2014: 27).

Wśród Chińczyków żywe jest przywiązanie nie tyle do zasad kodeksów prawnych i szeroko rozumianej legislacji tak cenionych w świecie Zachodu, lecz do zasad guanxi, które umożliwiają „, dogadywanie się” i rozwiązanie ewentualnych konfliktu i sporów bez uciekania się do składania sprawy w sądzie. Guanxi to kwintesencja zachowań społecznych Chińczyków, stojąca w sporej sprzeczności z zasadami sfor- 
malizowanej egzekucji prawnej cechującej świat Zachodu. Ten trwały element chińskiej mentalności napotyka na opór i stoi w kontrze do zachodniego bezwzględnego poszanowania „prawa pisanego”, mogąc rodzić konflikty negocjacyjne. Jeśli strony łączy guanxi, to elastyczność i niewidzialny związek takiego układu powodują, że przysługą płaci się za kolejną przysługę drugiej strony. Ten unikatowy mechanizm wzajemnej pomocy działa w Chinach od wieków, często skutkując tzw. „kapitalizmem kolesiowskim" (crony capitalism), w którym dominują koneksje, układy i znajomości „pachnące korupcją”. Dzieje się tak nawet pomimo tego, że guanxi pozostaje problemem w kontekście przestrzegania zasad etyki konfucjańskiej. Skutkuje ono tym, że wśród dużych i znaczących gospodarek w świecie Chiny zalicza się do najbardziej skorumpowanych. Tak przynajmniej wynika z zestawienia Corruption Perceptron Index 2015, co roku publikowanego przez Transparency International we współpracy z Ernst \& Young. ChRL znajduje się w nim na odległym 81 miejscu, mając gorsze wskaźniki niż Indie. Jedynie Rosja z grupy ważnych rynków wschodzących na 168 badanych gospodarek wypada gorzej. Najlepiej z kolei prezentują się państwa z Europy Zachodniej, w tym członkowie UE. Liderami pozostają Dania, Finlandia i Szwecja. Bardzo dobre oceny zebrały też Niemcy i Luksemburg (ibid.; Corruption Perception Index, 2015).

Obrazowo zagadnienie to na portalu GoChina.pl przedstawił M. Jawoszek, współwłaściciel aktywnej na rynku chińskim firmy Pronox Technology. W jego opinii:

„Guanxi jest pojęciem w Chinach bardzo ważnym, podobnie jak pragmatyzm czy pojęcie twarzy. Guanxi, czy relacja z naszym partnerem, to nie jest coś, co jest dane, zawsze zależy od indywidualnych cech danej osoby. Guanxi, jak nieraz porównywałem, to jest taki ogródek, który trzeba pielęgnować. W kontaktach, czy to świadomie, czy bezwiednie, zawsze przekazujemy sygnały, można powiedzieć, «pozycjonujemy się». Chińczycy starają się nas pozycjonować. Trzeba pamiętać, że to jest silnie zhierarchizowane społeczeństwo. Tam zawsze musi być jakaś hierarchia zachowana, w biznesie również. Poprzez naszą postawę, poprzez naszą pozycję, poprzez biznes, jaki robimy, czy jego skalę, tworzymy swój wizerunek w oczach Chińczyków, a oni nadają nam pewną wartość. [...] Plusem dla nas jest to, że jesteśmy cudzoziemcami, pewne niezręczności są nam wybaczane, bo nie znamy kultury, nie znamy języka itd. Ale jeśli będziemy aroganccy, szczególnie obecnie, to tracimy wszystko i będziemy wyrzuceni poza nawias. Natomiast bezpieczeństwo w biznesie nie opiera się na umowach, bo do tych Chińczycy podchodzą ambiwalentnie i pragmatycznie. Dopóki jest wszystko OK, oni traktują je jako pewną formalność. Kiedy zaczynają się kłopoty po ich stronie, to próbują sprawę lekceważyć mówiąc, że między przyjaciółmi najważniejsze jest porozumienie i mediacja. Dużo ważniejszym zabezpieczeniem jest właśnie guanxi. Jeśli nasza wartość przewyższa wartość kontraktu czy zamówienia, to zamówienie jest bezpieczne. Jeśli współpraca nam się układa, jeśli Chińczycy mogą się czegoś od nas nauczyć i wcale nie musi chodzić o sam zarobek. Wielu Chińczyków, chciałoby wysłać swoje dzieci za granicę, czy też ulokować swój kapitał poza Chinami. Do tego potrzebni są przyjaciele, którzy będą ich wspierać w tych działaniach. W kontaktach biznesowych mogą pojawić się nawiązania do tych tematów. Czy może można pomóc coś załatwić, czy też kimś czy czymś się zaopiekować. Tego typu postulaty pojawiają się na pewnym etapie znajomości, też nie pojawiają się zawsze i nie dotyczą każdego. Chińczycy wybierają konkretne osoby; potrafią wyczuć, z kim można rozmawiać, a z kim nie. Kto może pomóc, kto ma koneksje. Też nie zawsze chodzi o to, że tylko my sami stanowimy jakąś wartość. Wartość stanowią też 
nasze koneksje, też te, z których czasem sobie nie zdajemy sprawy. W oparciu o nie jesteśmy postrzegani i pozycjonowani” (Jak zrobić biznes w Chinach, 2016).

W taki właśnie sposób powstają lokalne, a nawet ogólnokrajowe i międzynarodowe nieformalne układy towarzyskie i biznesowe. Zaletą tych uzależnień jest potrójny, skuteczny dialog między kapitałem, pracą a administracją, wadą natomiast przeradzanie się stosunków gospodarczych we wspomniany crony capitalism, zwany też kapitalizmem pola golfowego, na którym to polu sportu popularnego wśród elit politycznych i biznesowych, owa sieć nieformalnych, korupcjogennych stosunków biznesowych, dalekich od etyki konfucjańskiej jest często umacniana. Relacje oparte na quanxi, choć wyjątkowo odległe od „ducha i litery” przesłań konfucjańskich, są nadal w Chinach powszechne ${ }^{13}$ (Weggel, 2006: 47).

\section{KOLEKTYWIZM I POZOSTALE WARTOŚCI AZJATYCKIE PRAKTYKOWANE W CHINACH}

Mieszkańcy państw azjatyckich w swojej motywacji częściej okazują otwartość i dostosowanie się do potrzeb innych ludzi. Szczególnie Chińczycy wykazują silną potrzebę społecznie zorientowanych osiagnięć, wytrzymałości, skromności i pielęgnacji. Mniejszą przywiązują do indywidualnych osiaggnięć, agresji i popisywania się. Kolektywiści podkreślają wysiłek swoich starań. Wśród indywidualistów podkreśla się umiejętności. Kolektywiści preferują postawy odzwierciedlające towarzyskość, współzależność oraz rodzinną integralność. Posiadanie odmiennego zdania niż reszta swojej grupy jest przykrym doświadczeniem dla jednostki. Najwyższą wartością jest dobro grupy. Kolektywiści cenią bezpieczeństwo, dobre relacje społeczne, harmonię wewnątrz grupy, spersonalizowane związki, wytrwałość, porządek społeczny, szacunek dla tradycji, rodziców i osób starszych, uprzejmość. W codziennym komunikowaniu się - częściej wykorzystują słowa „my” niż ,ja”. W kulturach kolektywistycznych częściej wybiera się, ocenia i promuje jednostki na podstawie ich lojalności oraz wieku i pozycji, niż na podstawie ich cech osobowych. Lepsze są pochwały kierowane nie wprost, co jest przeciwieństwem u indywidualistów. Największe znaczenie ekonomiczne dla Chińczyków implikuje kolektywizm i orientacja długoterminowa (ibid.; Musiałek, 2010: 34).

Wartości azjatyckie - z wyjątkiem quanxi - przenika więc duch konfucjanizmu, a ten jak już zauważono stanowi jeden $\mathrm{z}$ fundamentów chińskiego modelu rozwojowego. Świadomość społeczeństwa chińskiego, przez stulecia oparta była na systemie filozoficzno-religijnym wypracowanym, przez żyjącego w V w. p.n.e. Konfucjusza. Naśladowcy Mistrza Konga starają się dopasować swą postawę do reszty kolektywnego społeczeństwa i charakteryzuje ich posłuszeństwo wobec władców i przywódców. System wartości, który stworzył Konfucjusz wraz z reformami zainicjowanymi przez Denga na nowo stał się wzorcem zachowań dla setek milionów chińskich obywateli.

${ }_{13}$ Zob. również: X. Yao (2009), Konfucjanizm. Wprowadzenie, Kraków; F. Avanzini (2004), Religie Chin, Kraków; ks. A. Zwoliński (2007), Chiny - historia, teraźniejszość, Kraków; U. Płowiec (2008), Czynniki wzrostu i ekspansji Chin, w: Chiny - Indie. Ekonomiczne skutki rozwoju, (red.) K. Kłosiński, Lublin. 
Jest on zdecydowanie odmienny od wypracowanego w Europie i w Stanach Zjednoczonych, w którym najważniejsza jest jednostka i prawa jej przysługujące (Konfucjanizm i jego..., 2013).

\section{CZY CHINY ZDOMINUJĄ ŚWIAT?}

Patrząc z globalnej perspektywy, pełna i bezwarunkowa dominacja Chin w świecie wydaje się mało prawdopodobna. Owszem, ChRL może stać się silniejsza gospodarczo od Stanów Zjednoczonych, a tym bardziej od Unii Europejskiej traktowanych osobno ale w zasadzie porównując tylko jeden wskaźnik, czyli procentowy wkład w tworzenie zagregowanego globalnego PKB. Jednak to „globalne równanie” wygląda już inaczej, gdy obok USA postawi się w jednym szeregu Japonię, Koreę Południową oraz Indie, które do 2025 r. mogą zostać najludniejszym państwem na kuli ziemskiej. Należy dodać jeszcze do tej grupy Unię Europejską z najwyższym - jako region - PKB na świecie (ponad dwa razy większym niż PKB Chin) i jej 28 państw członkowskich, wliczając w to jedno mocarstwo ekonomiczne w postaci Niemiec oraz dwie czołowe gospodarki z rankingu światowych potęg - Francję i Wielką Brytanię. Gdyby rozmowy w sprawie wolnego handlu i inwestycji pomiędzy USA a UE, czyli umowa TTIP, zakończyły się sukcesem (co jest niestety mało prawdopodobne), podobnie jak umowa handlowa z Kanadą (CETA), a dodatkowo sprawnie funkcjonował układ handlowy TTP (zanegowany przez D. Trumpa), to Chiny stanęłyby przed ryzykiem wyboru pomiędzy pozostaniem w pewnej izolacji a dostosowaniem się do globalnych reguł ustanowionych przez innych, którzy nie są przychylni ich modelowi gospodarczemu i społecznemu. Jak słusznie dowodzi J. Fenby, na świecie jest wiele nacji, które niechętnie witają perspektywę chińskiej hegemonii. Państwa te muszą jednak wypracować sposób, w jaki zareagują na narodziny nowej potęgi globalnej, a jednym z rozwiązań jest nawiązanie bliższej współpracy między sobą w oparciu o wspólne systemy wartości. Nie stanowią one przy tym koalicji antychińskiej, ale ich działaniom może sprzyjać brak zdecydowanych sojuszników Chin. Tak czy inaczej, skala i tempo rozwoju ChRL nie może przesłaniać silnych stron reszty państw świata, które mogą pomóc w zachowaniu równowagi sił w obliczu zagrożenia, że wschodzące mocarstwo zdominuje arenę globalną w XXI wieku (Fenby, 2014: 28).

Argument o przewidywanej chińskiej dominacji jest równie trudny do podtrzymania, jeżeli chodzi o miękka siłę oddziaływania Chin w świecie. Pomimo aktywności ponad 700 Instytutów Konfucjusza, nauczania języka chińskiego, światowego zasięgu państwowej stacji CCTV i dziennika „China Daily”, niewiele osób przejmuje chiński styl życia i wartości. W Unii Europejskiej jedynie premier Węgier V. Orban oficjalnie wyraził się pozytywnie o chińskiej formule rozwojowej. W zjednoczonej Europie pomimo kryzysu gospodarczego i kryzysu samej idei integracji nie dąży się póki co do wprowadzenia systemów autokratycznych (część komentatorów politycznych wyklucza z tego grona Polskę). Nadal zdecydowanie silniejsze jest nawoływanie do demokracji liberalnej opartej na prawach konkurencji rynkowej niż apele o wprowadzenie zestawu hierarchicznych norm zachowania, które podkreślają znaczenie ,stosownych relacji, pomiędzy władcą a jego ministrem, ojcem a synem, przełożonymi i podwład- 
nymi, wysoko urodzonymi a plebsem, z których wszyscy są na swoim miejscu, tak jak kapelusze i buty nie mogą być używane zamiennie". Jednostki, firmy i społeczeństwo obywatelskie rozkwitają w mniej autorytarnych państwach niż ChRL i mogą zdziałać o wiele więcej niż w sytuacji, gdy większość sfer aktywności kontrolowana jest przez państwo. Podawane przez samych Chińczyków powody, dla których kupują oni towary wytworzone za granica, mówią wiele o zaletach tych produktów - ich oryginalności, wysokiej jakości i bezpieczeństwie, jak również o atrakcyjności samej marki zachodniego produktu. Nie ma więc wiele dowodów na poparcie tezy, że świat wkrótce stanie się bardziej chiński. Przeciwnie - wystarczy przejść się ulicami jakiegokolwiek miasta w Chinach, aby ujrzeć o wiele więcej wpływów świata zachodniego, od ubrań i okładek magazynów po restauracje typu fast food i fryzury przechodniów, niż śladów współczesnej kultury chińskiej na Zachodzie. Nadal wielu Chińczyków dąży do wyjazdu za granicę, głównie Ameryki Północnej, Australii i Nowej Zelandii. W 2011 r. 80 tysięcy Chińczyków uzyskało amerykańską zieloną kartę. Wśród najbardziej chętnych do emigracji są najwięksi beneficjenci systemu. Według badania z 2011 r. 27\% Chińczyków z majątkiem netto w wysokości co najmniej 100 milionów juanów uzyskało paszporty innych państw lub prawo stałego pobytu w nich. Dodatkowo $47 \%$ kolejnych osób z tej listy poważnie rozważało emigrację (ibid.). Ocenia się, że w $2011 \mathrm{r}$. odpływ kapitału wyniósł 600 miliardów dolarów. Ponad 85\% milionerów poddanych sondażowi w 2012 r. deklarowało, że planuje wysłać swoje dzieci do szkół za granicą. Córka Xi Jinpinga wyjechała studiować na Harvardzie (pod przybranym nazwiskiem), a syn Bo Xilai'a uczęszczał do szkoły Harrow w Anglii, Balliol College w Oxfordzie i do Harvard Kennedy School (ibid.).

Co więcej, w 2013 r. w corocznym rankingu ulubionych nacji świata przygotowanym przez $B B C$ ChRL znalazła się dopiero na 9 miejscu wśród 21 narodów. $42 \%$ respondentów wyrażało się o nich przychylnie, podczas gdy $39 \%$ oceniło je negatywnie. Liczba ocen negatywnych wzrosła jednak o 8 punktów procentowych w porównaniu z rokiem poprzednim. Demonstracje na rzecz demokracji na Bliskim Wschodzie i w Afryce przyciagają tłumy, ale nikt nie oręduje za chińskim modelem rządów. W samej ChRL wyniki sondażu agencji badawczej Pew z 2012 r. pokazuje, że 52\% Chińczyków podoba się amerykańska idea demokracji, a jedynie $29 \%$ ją odrzuca. Wśród respondentów o wyższych dochodach odsetek zwolenników tej idei wyniósł $70 \%$. W kolejnym roku liczba pozytywnych ocen Stanów Zjednoczonych wśród wszystkich respondentów wyniosła $63 \%$, podczas gdy odsetek pochlebnych ocen ChRL wyniósł $50 \%$. Aż $59 \%$ uznało, że USA jest odpowiednim partnerem dla ich kraju, podczas gdy jedynie 39\% wyraziło się w podobny sposób o Chinach. Nawet państwa, które wiele sprzedają do ChRL oraz zapraszają chińskie firmy do inwestowania w produkcję i zasoby naturalne na swoim terytorium, zgłaszają swoje zastrzeżenia. Powszechne są skargi na praktyki pracownicze w chińskich przedsiębiorstwach (ibid.).

Są i inne fakty, które w sposób rażący kontrastują z tym, co charakteryzowało Stany Zjednoczone w erze ich ekspansji globalnej. Pomimo rozwoju, Chiny nadal pozostaja potęgą uzależnioną od innych rynków: od importu minerałów (w 2012 r. jego wielkość osiagnęła 80\% globalnej podaży), ropy naftowej (w 2014 r. ChRL wyprzedziła Stany Zjednoczone i stała się największym nabywcą ropy na świecie), gazu (co wiąże się 
z jej planami zmniejszenia uzależnienia od węgla jako głównego źródła energii), oraz - w przypadku nieurodzaju - żywności i paszy dla zwierząt. Mieszkańcy ChRL stanowią 20\% światowej populacji, ale mniej niż połowa z nich mieszka na terenach uprawnych z odnawialnymi źródłami wody, a obydwa te kluczowe zasoby są zagrożone. Ponadto pomimo nagłaśnianych przez media i niektóre środowiska naukowe obaw, że Chiny „wykupują świat”, tak naprawdę, poza sektorem surowców naturalnych i branżą żywnościową, wartość ich inwestycji - choć rosnąca - jest stosunkowo niewielka. Natomiast bezpośrednie inwestycje zagraniczne w ChRL stale utrzymują się na dużo wyższym poziomie. Aktualne spowolnienie gospodarki chińskiej odbiło się również na kondycji przedsiębiorstw zagranicznych - 12 spośród 18 amerykańskich przedsiębiorstw, które prowadzą intensywną działalność biznesową w Chinach, zanotowały spadek wartości swych akcji na giełdzie nowojorskiej (indeks S\&P). Firmy notowane w indeksie Sinodependency opracowanym przez „The Economist”, który klasyfikuje amerykańskie przedsiębiorstwa pod względem wielkości ich przychodów w Chinach, od 2009 r. notują większe lub mniejsze straty. Wielu firmom zagranicznym jest dziś dużo trudniej penetrować rynek wewnętrzny, a niektóre z nich popadły w problemy z prawem, ponieważ zostały oskarżone o działalność monopolistyczną. Gospodarka chińska w niemałym stopniu pozostaje jednak uzależniona od firm z udziałem kapitału zagranicznego, które są odpowiedzialne za zdecydowaną większość chińskiego eksportu produktów wysokich technologii i know-how. Choć w Chinach działa większość spośród największych korporacji świata, co nie dziwi, jeśli weźmiemy pod uwagę wielkość rynku, koszty produkcji i tempo wzrostu PKB, najważniejsze z nich nadal mają swe centrale na Zachodzie i w Japonii. Duże chińskie przedsiębiorstwa (z kilkoma wszak wyjątkami!) nie przyciaggają klientów z zagranicy na tą skalę co firmy amerykańskie, europejskie, japońskie czy koreańskie, chyba że jako anonimowe firmy wykonujące montaż dla zagranicznych producentów. Nie mają też wyrazistego wizerunku marki (analogicznie i tu są wyjątki typu Lenovo, Huawei czy Haier) w przeciwieństwie do globalnie rozpoznawalnych produktów amerykańskich, europejskich, japońskich czy południowokoreańskich (ibid.).

Do problemu potencjalnej chińskiej dominacji ekonomicznej w świecie ciekawie odnosi się także Martin Jacques w książce pt. When China Rules the World. The End of the Western World and the Birth of a New Global World. W jego opinii „można z dużą dozą pewności założyć, że Chiny nie zejdą z drogi rozwoju. Stopa wzrostu gospodarczego jednak na pewno z czasem się zmniejszy. Tak naprawdę, ten proces się już rozpoczął. Państwo Środka musi dziś zmierzyć się z wyzwaniem, jakim jest przejście od zorientowanej na eksport, pracochłonnej gospodarki, do gospodarki wysoce innowacyjnej i kapitałochłonnej, która jest w dużo mniejszym zakresie uzależniona od eksportu. W dużo większym stopniu jest ona zależna od konsumpcji wewnętrznej i przeznacza na inwestycje coraz mniejszy odsetek swego PKB" (Jacques, 2012: 34).

Entuzjastów modelu wzrostu gospodarczego opartego na eksporcie i inwestycjach skrytykował też czołowy chiński ekonomista Yu Yongding, stwierdzając że w Chinach konieczne są głębokie reformy. „Chiny znalazły się w krytycznym punkcie: bez bolesnych przekształceń strukturalnych ich wzrost gospodarczy może nagle stracić rozpęd" zauważył Yu (ibid.). 
Prawdopodobnie w nadchodzącej dekadzie stopa wzrostu w ChRL będzie nadal spadać, osiagając poziom bliski 5-6\%. Państwo Środka będzie musiało stawić czoła problemowi starzenia się populacji, która będzie coraz bardziej zależna od aktywnej zawodowo części społeczeństwa. Spadek tempa wzrostu gospodarczego jest jednak raczej nieunikniony, choć zjawisko to w żaden sposób nie podważy idei chińskiego modelu rozwoju i przekonania, że ChRL osiagnie pozycję jednej z dwóch największych potęg gospodarczych w świecie (wraz z USA), a ostatecznie, uzyska status globalnego supermocarstwa. Należy zatem zastanowić się jakie będą Chiny jako globalny hegemon. Jaki będzie zasięg ich potęgi i jakie formy ona przyjmie? Oczywiste jest, że odpowiedzi uzależnione są również od analizy elementów zewnętrznych. Pierwszym z nich są Stany Zjednoczone i pytanie jak szybko stracą swą pozycję hegemona i jaką strategię względem ChRL przyjmą? Nie można również zapominać o Europie i Japonii, które będą tracić na znaczeniu, szczególnie jeśli nie zdecydują się na bliską współpracę handlową i inwestycyjną z USA (UE - TTIP). Czy antidotum na rosnącą potęgę ChRL w świecie może stać się umowa TTIP? Czy w relacjach bilateralnych ChRL-UE przeważy obustronnie korzystna kooperacja czy coraz bardziej bezpośrednia i nie zawsze uczciwa ze strony chińskiej - jak do tej pory - konkurencja?

Cytowany chiński ekonomista słusznie dowodzi, że zmierzamy w kierunku świata wielobiegunowego, ale to, ile tych biegunów będzie, i w jaki sposób się ukształtują relacje między nimi, nadal pozostaje kwestią otwartą. Gdy próbujemy zrozumieć, jak będzie wyglądał przyszły światowy ład ekonomiczny z wiodącą rolą ChRL, czyli Pax Sinica, jak będzie się różnił od dawnych hegemonii i czy zastąpi porządek globalny oparty przez dekady na Pax Americana, warto się przyjrzeć jakie są i jakie były, główne cechy globalnej dominacji Ameryki w świecie. Póki co bowiem Stany Zjednoczone nadal: 1) są największą gospodarką świata; 2) mają jeden z najwyższych na świecie PKB per capita, szczególnie w tak dużych gospodarkach; 3) mają najbardziej zaawansowaną technologicznie i innowacyjną gospodarkę na świecie; 4) są zdecydowanie najsilniejszą potęgą militarną świata, co pozwala jej mieć wpływy w każdym rejonie świata dzięki ogromnej flocie morskiej i powietrznej; 5) ich ogólna potęga globalna oznacza, że każde państwo musi uznawać stosunki z USA za kluczowe w swej polityce zagranicznej. W rezultacie wszystkie państwa mają do pewnego stopnia ograniczoną suwerenność, od Wielkiej Brytanii i Izraela po Meksyk, a nawet ...Chiny; 6) międzynarodowy system gospodarczy został w głównej mierze zaprojektowany i ukształtowany przez Stany Zjednoczone, które ustanowiły również rządzące nim zasady (ONZ, MFW, Bank Światowy, WTO); 7) w Stanach Zjednoczonych mieści się większość najlepszych uczelni wyższych świata i od dawna przyciagają one najlepsze talenty naukowe $\mathrm{z}$ innych państw; 8) język angielski stał się lingua franca $\mathrm{w}$ dużej mierze dzięki potędze i sile oddziaływania Stanów Zjednoczonych; 9) Hollywood zdominowało globalny rynek filmowy, jak również, w nieco mniejszym stopniu, rynek telewizyjny; 10) amerykańskie marki, takie jak Google, Microsoft, Coca-Cola czy Walmart dominują nad markami z innych państw i są obecne na całym świecie; 11) historia Stanów Zjednoczonych stała się elementem światowego dziedzictwa kulturowego, ze swymi najbardziej znanymi wydarzeniami i symbolami, takimi jak Deklaracja Niepodległości, wojna secesyjna, które znane są całemu światu. Podobnie amerykańskie 
zwyczaje, zyskały większą lub mniejszą popularność na wszystkich kontynentach; 12) amerykańskie wartości - czy to indywidualizm, demokracja, prawa człowieka, czy też neoliberalizm, neokonserwatyzm, rynek i wolność - wciąż znajdują oddźwięk w wielu regionach świata (ibid.).

$$
* * *
$$

Szukając odpowiedzi na postawione we wstępie pracy pytanie badawcze, należy stwierdzić, że chiński model rozwoju posiada zdecydowanie unikatowy charakter. Bez wątpienia - pomimo niemałych kosztów społecznych i ekologicznych - służy on przyspieszonemu rozwojowi społeczno-gospodarczego ChRL. Jest on głęboko zakorzeniony w wielowiekowej azjatyckiej tradycji, kulturze, filozofii i religii, którym odpowiada właściwa struktura i mentalność społeczna. Jak zresztą, przynajmniej oficjalnie, podkreślają sami Chińczycy modelu ich rozwoju nie należy naśladować $\mathrm{w}$ innych państwach i na innych niż azjatycki kontynentach. Jeśli gdzieś w świecie podejmuje się ryzykowne próby naśladowania chińskiej formuły rozwojowej, to dzieje się to na takich kontynentach jak afrykański czy południowoamerykański oraz w Azji Centralnej, w krajach słabiej rozwiniętych z wyraźnym deficytem demokracji i tendencjami autorytarnymi ze strony rządzących. Chińskie korporacje, szczególnie w branży surowcowej są w nich od lat są bardzo aktywne, a bilateralna, wielowymiarowa współpraca handlowa i inwestycyjna intensywnie się rozwija lub rozwijać się będzie, ale na chińskich zasadach (Nowy Jedwabny Szlak). Europa i jej wielowiekowa chrześcijańska tradycja, współcześnie spleciona z wieloma elementami państwa świeckiego, szczególny nacisk kładzie na takie wartości jak: prawa człowieka (w tym pracownika) i wolności obywatelskie, demokracja deliberatywna i społeczeństwo obywatelskie, wolne wybory, przejrzystość życia publicznego i wolność słowa, tolerancja (w tym problematyka gender studies), równość i sprawiedliwość społeczna, szacunek wobec prawa pisanego, indywidualizm, etyczny biznes (propagowana idea społecznej odpowiedzialności biznesu - CSR) czy ochrona środowiska naturalnego (w zgodzie z paradygmatem trwałego i zrównoważonego rozwoju). Hierarchiczny, patriarchalny i kolektywny charakter społeczeństwa chińskiego oraz na nowo odkryte i selektywnie propagowane wartości konfucjańskie wyraźnie nie pasują do profilu aksjologicznego przeciętnego Europejczyka, jego stylu życia i pracy. O ile więc opresyjny system meldunkowy hukou (zasługujący na osobną analizę) czy powszechnie aprobowane i stosowane guanxi (akurat sprzeczne z filozofią konfucjańską) stanowią w ChRL powszechnie akceptowaną normę społeczną, o tyle w Europie, a szczególnie Unii Europejskiej są absolutnie niemożliwe do wdrażania i akceptacji. Kryzys wartości europejskich jakiego jesteśmy aktualnie świadkami nie może przesłaniać widocznych mankamentów chińskiego modelu rozwoju, jego niemożności powielania poza Azją Wschodnią oraz unikalności kulturowej, filozoficznej i religijnej. Natomiast takie elementy jak długofalowe, spójne, strategiczne myślenie o rozwoju kraju, planowe i etapowe działania na rzecz jego modernizacji oraz duża, stymulująca funkcjonowanie rynku rola państwa z planowaniem gospodarczym na czele, mogą już stanowić ciekawy punkt odniesienia i pewien wzorzec do naśladowania dla pogrążonej w stagnacji gospodarczej Europy. Skoordynowane działania na poziomie ponadnarodowym w UE, mogą pozwolić zin- 
tegrowanej Europie wychodzić z kryzysu skuteczniej będąc przejawem myślenia długofalowego i strategicznego tak bardzo charakterystycznego dla współczesnych Chin. Ważne, aby w ślad za tym szła spójna, dalekowzroczna polityka zagraniczna (w tym gospodarcza) realizowana na poziomie państw członkowskich Unii Europejskiej. Bezrefleksyjne wpuszczanie na swój rynek szeroko dotowanych korporacji chińskich i produktów, których konkurencyjność sztucznie wzmacnia nieodszacowany juan (renminbi) i liczne praktyki ochrony rynku i dumpingu w handlu, prędzej czy później działać będzie na niekorzyść firm i konsumentów europejskich. Większy nadzór i kontrola na poziomie ponadnarodowym, czyli Jednolitego Rynku Wewnętrznego, na wzór instytucji amerykańskich jest wręcz w Europie niezbędny.

Czy świat skazany jest na długofalową chińską dominację gospodarczą? Jeśli w łonie Unii Europejskiej przeważy rozsądek i dojdzie do podpisania i ratyfikowania umowy TTIP oraz uda się jej wypracować spójną strategię negocjacyjną względem Chin, równoprawne warunki handlowe i inwestycyjne, uczciwą konkurencję zgodnie $\mathrm{z}$ formułą win-win, to wielce prawdopodobne, że do scenariusza tego nie dojdzie. W przeciwnym razie Pax Sinica już za dwie - trzy dekady może stać się faktem, służąc przede wszystkim Chinom. Jest oczywiście niemożliwe, aby dziś w $100 \%$ przewidzieć, z czym przede wszystkim będziemy kojarzyć potencjalną przyszłą hegemonię chińską w świecie, ale poszukiwanie odpowiedzi w obszarze krytycznej analizy cech konsensu pekińskiego i prób jego potencjalnej adaptacji wydaje się być najbliższe prawdzie.

\section{BIBLIOGRAFIA}

Allison G., Blackwill R. D., Wyne A. (2013), Chiny, Stany Zjednoczone i świat w oczach Wielkiego Mistrza Lee Kuan Yewa, Warszawa.

Avanzini F. (2004), Religie Chin, Kraków.

Bolesta A. (2006), Chiny w okresie transformacji, Warszawa.

Brunet A., Guichart J-P. (2011), Chiny światowym hegemonem. Imperializm ekonomiczny Państwa Środka, Warszawa.

Chołaj H. (2014), Kapitalizm konfucjański. Chińskie reformy ekonomiczne a globalizacja, Warszawa.

Cohen D. (2011), Prosperity stabości, Warszawa.

Corruption Perceptron Index 2015, Transparency International - The global coalition against corruption, http//transparency.org (16.09.2016).

Dillon M. (2014), Chiny. Historia wspótczesna, Warszawa.

Fenby J. (2014), Will China Dominate the 21st Century?, Cambridge.

Giford R. (2013), Chińska droga. Podróże w głab Państwa Środka, Warszawa.

Gittings J. (2010), Historia wspótczesnych Chin. Od Mao do gospodarki rynkowej, Kraków.

Góralczyk B. (2010), ,, Chiński feniks”. Paradoksy wschodzqcego mocarstwa, Warszawa.

Góralczyk B. (2010), Wokót chińskiego modelu rozwojowego. W odpowiedzi R. Pyfflowi, http//polska-azja.pl (9.08.2016).

Gradziuk A., Szczudlik-Tatar J. (2012), Perspektywy rozwoju wspótpracy gospodarczej Polski z Chińskq Republikq Ludowq, Warszawa. 
Halper S. (2010), The Beijing Consensus: How China's Authoritarian Model Will Dominate the Twenty-first Century, New York.

Inwestowanie w Chinach, KPMG China Practice w Polsce, http//kpmg.pl (7.09.2016).

Jacques M. (2012), When China Rules the World: The End of the Western World and the Birth of a New Global Order, Second Edition 2, New York.

Jak zrobić biznes w Chinach. Rozmowa z Mariuszem Jawoszkiem, współwłaścicielem Pronox Technology, http://www.goldenline.pl/grupy/Przedsiebiorcy_biznesmeni/bizneschiny-com/jakzrobic-biznes-w-chinach,355998/ (9.08.2016).

Kagan R. (2009), Powrót historii i koniec marzeń, Poznań.

Kaliński A. (2014), Chiny: obywatel ze wsi obywatelem I kategorii, http://www.obserwatorfinansowy.pl/forma/rotator/chiny-obywatel-ze-wsi-obywatelem-i-kategorii/ (14.09.2016).

Kamiński T. (2014), Po pierwsze gospodarka. Narzędzia polityki zagranicznej ChRL wobec Unii Europejskiej, w: Narzędzia polityki zagranicznej Chińskiej Republiki Ludowej, (red.) M. Pietrasiak, D. Mierzejewski, K. Żakowski, Łódź.

Kamiński T. (2014b), Chińska soft power a ambicje globalne Unii Europejskiej, w: Współczesne Chiny w kontekście stosunków międzynarodowych, (red.) J. Wardęga, Kraków.

Kissinger H. (2014), O Chinach, Wołowiec.

Kłosiński K. (2008), Chiny polityka otwartych drzwi «China OpenDoor Policy», „Annals of Social Sciences” („Roczniki Nauk Społecznych”), nr 3.

Lampton D. M. (2014), Following the Leader. Ruling China, from Deng Xiaoping to Xi Jinping, Berkeley, Los Angeles, London.

Leonard M. (2009), Zrozumieć Chiny (wstęp od wydawcy), Warszawa.

Liberska B. (2010), Perspektywy rozwojowe chińskiej gospodarki do 2050 roku «Prospects for Development of Chinese Economy Till Year 2050, „Economic Studies” („Studia Ekonomiczne"), $\mathrm{nr} 4$.

Liberska B., Czy Beijing consensus zastapi waszyngtoński?, http://www.obserwatorfinansowy. $\mathrm{pl} / 2010 / 03 / 11 /$.

Mann J. (2007), The China Fantasy. Why Capitalism Will Not Bring Democracy to China, New York.

Musiałek A. (2010), Konfucjanizm, w: Globalizacja - motor czy hamulec w stosunkach międzynarowych?, (red.) B. Bednarczyk, nr 3 (VII), Kraków.

Pieczonka A. (2012), Chińskie „, Go Global”. Dylematy i wyzwania dla Chińskiego Smoka, Szanghaj, http://www.gochina.gov.p1/ (17.09.2016).

Płowiec U. (2008), Czynniki wzrostu i ekspansji Chin, w: Chiny-Indie. Ekonomiczne skutki rozwoju, (red.) K. Kłosiński, Lublin.

Puślecki Z. W., Walkowski M., Szymczyński T. R. (2011), Unia Europejska wobec wzrostu konkurencyjności Brazylii, Rosji, Indii i Chin (BRIC), Warszawa.

Pyffel R. (2013), Chiny a kryzys demokracji. Czy model chiński zagrozi demokracji?, http.polskaazja.pl (9.08.2016).

Rowiński J. (2008), Chiny. Nowa globalna potega, w: Dokąd zmierza świat, (red.) A. D. Rotfeld, Warszawa.

Sachs J. D. (2005), The End of Poverty. How We Can Make it Happen in Our Lifetime, New York.

Seintz K. (2013), Chiny. Powrót olbrzyma, Warszawa.

Schell O., Delury J. ( 2013), Wealth and Power. China's Long March to the Twenty-First Century, New York.

Sławiński R. (red.) (2013), Konfucjanizm i jego wspótczesne interpretacje, Warszawa. 
Słowniczek pojęć, http://www.gochina.gov.pl/ (5.05.2016).

Tomalin B., Nicks M. (2014), Światowe kultury biznesu, Warszawa.

Weggel O. (2006), Chiny, Warszawa.

Yao X. (2009), Konfucjanizm. Wprowadzenie, Kraków.

Zwoliński A. (2007), Chiny - historia, teraźniejszość, Kraków.

\title{
STRESZCZENIE
}

Nagłaśniane od ponad trzech dekad sukcesy gospodarcze ChRL spowodowały, że w ostatnich latach znaczenia nabrała debata nie tylko na temat specyficznych cech, ale i potencjalnej uniwersalności tzw. chińskiego modelu rozwoju, zwanego najczęściej Konsensusem Pekińskim lub autorytarnym modelem kapitalizmu państwowego (state capitalism). Model ten ostatnimi laty stał się bardzo atrakcyjny dla wielu rządów, głównie słabiej rozwiniętych państw w świecie. Szczególnie widoczne jest to w Afryce, Ameryce Łacińskiej i Azji Centralnej, gdzie wyjątkowo aktywne są chińskie przedsiębiorstwa i politycy. Trwający od $2008 \mathrm{r}$. globalny kryzys finansowy i ekonomiczny w wielu regionach świata podważył zaufanie do anglosaskiego modelu gospodarki wolnorynkowej i towarzyszącej mu ideologii neoliberalnej. Szybkość, z jaką Chiny przeszły ze statusu biednego kraju rolniczego do globalnej potęgi gospodarczej, budzi podziw w wielu społeczeństwach. Także w Unii Europejskiej trwa debata na temat kształtowania prawidłowych relacji handlowo-inwestycyjnych z Chinami i oceny chińskiej formuły rozwojowej. Dyskusja dotyczy korzyści i kosztów społeczno-ekonomicznych chińskiej formuły rozwojowej oraz jej adaptowalności. Zauważalnej intensyfikacji uległa ona w kontekście realizacji i popularyzacji chińskiej koncepcji połączenia Azji z Europa, czyli projektu Pasa i Drogi (One Belt One Road). Autor w prezentowanym artykule pragnie przybliżyć specyfikę chińskiego modelu rozwoju, przedstawić jego silne i słabe strony na poszczególnych etapach rozwoju i dać odpowiedź na pytanie na ile użyteczny byłby on w Unii Europejskiej, zarówno na poziomie porozumień bilateralnych, jak i strategicznego partnerstwa Chin z całą UE.

Słowa kluczowe: Chiny, gospodarka rynkowa, model rozwoju, kapitalizm konfucjański, wartości azjatyckie, wzrost ekonomiczny

\section{CHINESE MODEL OF SOCIO-ECONOMIC DEVELOPMENT AND ITS POTENTIAL ADAPTATION IN EUROPE}

\begin{abstract}
For the last three decades the economic success enjoyed by the People's Republic of China has been closely followed around the world. Lately it has fuelled the debate about not only particular characteristics, but also potential universality of the so-called Chinese development model, often described as the Beijing Consensus or an authoritarian model of state capitalism. This model has lately become attractive for many governments, especially of the less developed states. It is especially visible in Africa, Latin America and Central Asia where Chinese companies and politicians are very active. Since 2008, in many regions of the world, global financial and economic crisis has eroded trust in the Anglo-Saxon model of free market economy and the accompanying neoliberal ideology. The speed with which China moved from a status of a poor
\end{abstract}


agricultural country to one of a global economic power has elicited admiration in many societies. In the European Union there is also a debate about an appropriate shape of trade-investment relations with China and evaluation of the Chinese development formula. The socioeconomic costs and benefits of the Chinese development formula, as well as its adaptability are being discussed. This debate has visibly intensified in the context of implementation and popularization of the Chinese concept concerning connecting Asia with Europe through the One Belt One Road project. In this article the author aims to describe the characteristics of the Chinese development model, present its strengths and weaknesses in different states of development and answer the question of how useful it could be for the European Union, both on the level of bilateral agreements and of a strategic partnership between China and the EU as a whole.

Keywords: China, market economy, development model, Confucian capitalism, Asian values, economic growth 
